Article

\title{
Five Novel Freshwater Ascomycetes Indicate High Undiscovered Diversity in Lotic Habitats in Thailand
}

\author{
Mark S. Calabon ${ }^{1,2}$ D, E. B. Gareth Jones ${ }^{3}$, Saranyaphat Boonmee ${ }^{1,2}$, Mingkwan Doilom ${ }^{4,5,6,7}$ (D), \\ Saisamorn Lumyong 4,5,8 and Kevin D. Hyde 1,2,4,5,7,*
}

1 Center of Excellence in Fungal Research, Mae Fah Luang University, Chiang Rai 57100, Thailand; mscalabon@up.edu.ph (M.S.C.); saranyaphat.boo@mfu.ac.th (S.B.)

2 School of Science, Mae Fah Luang University, Chiang Rai 57100, Thailand

3 Department of Botany and Microbiology, College of Science, King Saud University, P.O Box 2455, Riyadh 11451, Saudi Arabia; torperadgj@gmail.com

4 Department of Biology, Faculty of Science, Chiang Mai University, Chiang Mai 50200, Thailand; j_hammochi@hotmail.com (M.D.); scboi009@gmail.com (S.L.)

5 Research Center of Microbial Diversity and Sustainable Utilization, Chiang Mai University, Chiang Mai 50200, Thailand

6 CAS Key Laboratory for Plant Diversity and Biogeography of East Asia, Kunming Institute of Botany, Chinese Academy of Sciences, Kunming 650201, China

7 Innovative Institute for Plant Health, Zhongkai University of Agriculture and Engineering, Guangzhou 510225, China

8 Academy of Science, The Royal Society of Thailand, Bangkok 10300, Thailand

* Correspondence: kdhyde3@gmail.com

Citation: Calabon, M.S.; Jones, E.B.G.; Boonmee, S.; Doilom, M.; Lumyong, S.; Hyde, K.D. Five Novel Freshwater Ascomycetes Indicate High Undiscovered Diversity in Lotic Habitats in Thailand. J. Fungi 2021, 7, 117. https://doi.org/10.3390/jof7020117

Academic Editor: Lei Cai

Received: 29 December 2020

Accepted: 30 January 2021

Published: 5 February 2021

Publisher's Note: MDPI stays neutral with regard to jurisdictional claims in published maps and institutional affiliations.

Copyright: () 2021 by the authors Licensee MDPI, Basel, Switzerland. This article is an open access article distributed under the terms and conditions of the Creative Commons Attribution (CC BY) license (https:// creativecommons.org/licenses/by/ $4.0 /)$

\begin{abstract}
An investigation of freshwater fungi in Thailand resulted in the collection of one new monotypic genus, Neoxylomyces, and a novel species each in Camposporium, Brunneofusispora, Rattania, Neoxylomyces, and Phaeoacremonium. Camposporium dulciaquae resembles C. septatum in conidial morphology and number of septa but differs in conidial sizes. Brunneofusispora hyalina is similar to $B$. sinensis in conidiogenesis and conidial shape but differs in the sizes of conidiomata and conidiogenous cells. Rattania aquatica is the second species in Rattania, while Phaeoacremonium thailandense is the third species recorded from freshwater habitats. A new genus, Neoxylomyces, typified by N. multiseptatus, is similar to Xylomyces giganteus, but differs in the number of septa, chlamydospore measurements, and absence of a mucilaginous coating around the chlamydospores. These novel taxa form an independent lineage distinct from other species based on multi-loci phylogenetic analyses. Descriptions, illustrations, and notes are provided for each taxon. These new freshwater ascomycetes add to the increasing number of fungi known from Thailand and it is now evident that there are numerous novel taxa awaiting to be described as new freshwater habitats are explored. An update of newly discovered taxa in the widely studied freshwater habitats of Thailand over the last five years is also provided.
\end{abstract}

Keywords: 6 new taxa; aquatic fungi; Dothideomycetes; freshwater fungi; multi-loci phylogenetic analyses; Neoxylomyces; Sordariomycetes; tropical mycology

\section{Introduction}

Freshwater fungi are a diverse and heterogenous taxonomic group occurring on a wide variety of substrates and with a global distribution [1-4]. Jones et al. [2] estimated the number of freshwater fungi to be between 3069-4145, which is lower as compared to marine fungi with an estimated 12,500 species [5,6]. There are 1898 species under 767 genera of marine fungi listed in www.marinefungi.org (accessed on 13 January 2021) [6], but there are no recent published reports of freshwater fungal numbers [2,7]. An online platform on freshwater fungi, www.freshwarterfungi.org (accessed on 13 January 2021). is presently being compiled. This comprehensive database presently includes 451 species of freshwater 
Sordariomycetes, while the outline of freshwater Dothideomycetes is in preparation [8]. Many habitats and substrates are still not well-explored and freshwater fungi are likely to be more numerous than those thriving in marine environments.

Freshwater fungi have been relatively well-studied in Asia over the past decade, particularly in China and Thailand. Several new taxa have been introduced and existing taxa lacking molecular data have been recollected and sequenced resolving their taxonomic placements [8-13]. Several monographs and taxonomic revisions of freshwater fungi have also been published [10,14-16]. In Thailand, Zhang et al. [17] listed 173 species belonging to 112 genera recorded from freshwater habitats in 2010. Hu et al. [18] reported 782 species of freshwater fungi in China. Since then, many additional novel taxa have been described in these countries, bringing the number even higher (see [9-11,14,19-26]. In this paper, six novel taxa of freshwater ascomycetes in Thailand are introduced by combining multiloci phylogeny and morphology approaches. It appears that there are numerous new taxa awaiting to be discovered and described as new freshwater habitats are explored, or a particular genus is studied with molecular data, wherein its diversity is much higher than previously anticipated $[10,14,25,27]$.

We are carrying out surveys of freshwater fungi on submerged wood in streams along a north-south gradient in the Asia region [28] and here we introduce one new genus, Neoxylomyces (Phyllachorales genera incertae sedis, Phyllachorales), and one new species in each of Camposporium (Melanommataceae, Pleosporales), Brunneofusispora (Occultibambusaceae, Pleosporales), Rattania (Chaetosphaeriaceae, Chaetosphaeriales), and Phaeoacremonium (Togniniaceae, Togniniales).

\section{Materials and Methods}

\subsection{Sample Collection, Morphological Observation, and Fungal Isolation}

Samples of submerged decayed wood were collected from a freshwater stream in Chiang Mai Province $\left(19^{\circ} 07.200^{\prime} \mathrm{N}, 98^{\circ} 44.044^{\prime} \mathrm{E}\right)$ and river in Tak Province in Thailand $\left(17^{\circ} 28^{\prime} 20.7834^{\prime \prime} \mathrm{N}, 98^{\circ} 1^{\prime} 16.3236^{\prime \prime} \mathrm{E}\right)$ and treated as detailed in Senanayake et al. [29]. The samples were incubated for five days and periodically observed using stereomicroscope to check the presence of fruiting bodies. Micromorphological features were photographed using a Motic SMZ 168 Series dissection microscope for fungal structures on the woody substrate while microscopic characters were documented using Nikon Eclipse $80 \mathrm{i}$ microscope-camera system. Tarosoft (R) Image FrameWork was used to measure the micromorphological characters and photographic plates' preparation was done using Adobe Photoshop CC 2020. The mean size/length of at least 10 ascomata/conidiomata, 20 conidiophores, 20 asci, and 30 conidia / ascospores were measured and recorded. Single-spore isolation was used to obtain pure cultures and colonial characteristics in malt extract agar (MEA) were described. Herbarium type specimens were deposited in Mae Fah Luang University (MFLU). Ex-type living cultures were deposited at Mae Fah Luang University Culture Collection (MFLUCC). The new species were registered in Faces of Fungi (http:/ /http:/ /www.facesoffungi.org/ (accessed on 13 January 2021)) [30] and MycoBank databases (https:/ / www.mycobank.org/ (accessed on 13 January 2021)) [31]

\subsection{DNA Extraction, PCR Amplification, and Sequencing}

DNA extraction, polymerase chain reaction (PCR) amplification, agarose gel electrophoresis, PCR product purification, and sequencing were carried out as detailed in Dissayanake et al. [32] with the following modifications. Fungal mycelia from pure cultures grown in malt extract agar (MEA) $\left(\right.$ Difco $\left.^{\mathrm{TM}}\right)$ for 30 days were scraped using a sterilized scalpel and kept in a $1.5 \mathrm{~mL}$ microcentrifuge tube. Genomic DNA was extracted using a Biospin Fungus Genomic DNA Extraction Kit (BioFlux ${ }^{\circledR}$, Hangzhou, China) following the manufacturer's protocol. Polymerase chain reaction (PCR) was used to amplify six markers: the nuclear ribosomal large subunit $28 \mathrm{~S}$ rRNA gene (LSU), the nuclear ribosomal small subunit $18 \mathrm{~S}$ rRNA gene (SSU), nuclear ribosomal internal transcribed spacers (ITS), and fragments of the translation elongation factor 1-alpha (TEF1- $\alpha$ ), $\beta$-tubulin (TUB2) and 
Actin (ACT) genes. LSU was amplified using the primers LROR and LR5 [33], while SSU was amplified using the primers NS1 and NS4 [34]. For ITS, primers ITS5 and ITS4 were used [34]. TEF1- $\alpha$ was amplified using primers EF1-983F and EF1-2218R [35]. Partial regions of the TUB2 and $A C T$ gene were amplified using the primer pairs T1 [36] and Bt2b [37], ACT-512F and ACT-783R [38], respectively. Polymerase chain reaction was performed in a volume of $25 \mu \mathrm{L}$, which contained $12.5 \mu \mathrm{L}$ of $2 \times$ Power Taq PCR Master Mix (Bioteke Co., Jiangsu, China), $1 \mu \mathrm{L}$ of each primer $(10 \mu \mathrm{M}), 1 \mu \mathrm{L}$ genomic DNA, and $9.5 \mu \mathrm{L}$ deionized water. The PCR thermal cycle programs for LSU, SSU, ITS and TEF1- $\alpha$ amplification were as follows: initial denaturing step of $94^{\circ} \mathrm{C}$ for $3 \mathrm{~min}$, followed by 40 cycles of denaturation at $94{ }^{\circ} \mathrm{C}$ for $45 \mathrm{~s}$, annealing at $51^{\circ} \mathrm{C}$ (TUB2) or $60^{\circ} \mathrm{C}$ (ACT) or $55^{\circ} \mathrm{C}$ (ITS, LSU, SSU, TEF1- $\alpha$ ) for $50 \mathrm{sec}$, elongation at $72{ }^{\circ} \mathrm{C}$ for $1 \mathrm{~min}$, and final extension at $72{ }^{\circ} \mathrm{C}$ for $10 \mathrm{~min}$. Agarose gel electrophoresis was done to confirm the presence of amplicons at the expected molecular weight. PCR products were purified and sequenced with the primers mentioned above at a commercial sequencing provider (Beijing Qingke Biotechnology Co., Ltd., Beijing, China). A BLAST search of the newly generated sequences was carried out to exclude contamination and to search for related taxa in GenBank database (www.ncbi.nlm.nih.gov/blast/ (accessed on 13 January 2021)).

\subsection{Phylogenetic Analyses}

Multi-loci phylogenetic analysis followed Dissayanake et al. [32]. The taxa table was assembled based on the closest matches from the BLASTn search results and from recently published data. Sequences generated from each marker were analyzed along with other sequences retrieved from GenBank. The individual loci matrix was aligned with MAFFT v.7 using the web server (http:/ / mafft.cbrc.jp/alignment/server (accessed on 13 January 2021); [39]) with the following settings: L-INS-i tree-based iterative refinement methods, $20 \mathrm{PAM} / \mathrm{k}=2$ scoring matrix for nucleotide sequences and 1.53 gap opening penalty. Alignment was further refined manually, where necessary, using BioEdit v.7.0.9.0 [40]. Aligned sequences were automatically trimmed using TrimAl v. 1.3 on the web server (http:/ / phylemon.bioinfo.cipf.es/utilities.html (accessed on 13 January 2021)) with the gappyout method. The online tool "ALTER" was used to convert the alignment file to phylip and nexus formats [41]. Phylogenetic analyses of both individual and combined gene data were performed using maximum likelihood (ML) and Bayesian inference (BI).

Maximum likelihood analysis was performed using RAxML-HPC2 on XSEDE on the CIPRES web portal [42-44] (http:/ / www.phylo.org/portal2/ (accessed on 13 January 2021); [45]). The GTR + GAMMA model of nucleotide evolution was used. RAxML rapid bootstrapping of 1000 replicates was performed. The best-fit evolutionary models for individual and combined dataset were estimated under the Akaike Information Criterion (AIC) using jModeltest 2.1.10 on the CIPRES web portal and each resulted to GTR + I+G model [46]. Bayesian inference analyses was performed using MrBayes v. 3.2.6 on XSEDE at the CIPRES webportal [47]. The parameter setting of the Bayesian analysis is detailed on the phylogenetic trees of each species. Trees were sampled every 100 generations and all other parameters were left as default. Newly generated sequences were deposited in GenBank, and alignments and trees were deposited in TreeBASE (www.treebase.org (accessed on 13 January 2021)).

\section{Results}

3.1. Taxonomy

3.1.1. Dothideomycetes O.E. Erikss. \& Winka, Myconet 1(1): 5 (1997)

Dothideomycetes are characterized by bitunicate asci with fissitunicate dehiscence, and ascolocular ascomatal development [15,48]. The class comprises 38 orders and 211 families and is considered to be the largest and most ecologically diverse class of ascomycetes [49]. Two new taxa are introduced in this article.

Pleosporales Luttr. ex M.E. Barr, Prodr. Cl. Loculoasc. (Amherst): 67 (1987) 
Wijayawardene et al. [49] listed 91 families and 566 genera under Pleosporales, with 48 genera in Pleosporales incertae sedis. It is the largest order of Dothideomycetes with members characterized mostly by flask-shaped pseudothecia [48]. In this paper, two new pleosporalean fungi are documented.

Melanommataceae G. Winter, Rabenhorst's Kryptogamen-Flora, Pilze-Ascomyceten, Edn 2 1(2): 220 (1885)

Melanommataceae was introduced by Winter [50] and Melanomma was regarded as the type genus based on its diagnostic character of trabeculate pseudoparaphyses. The latest treatment of the family by Hongsanan et al. [15] and Wijayawardene et al. [49] with 33 accepted genera in Melanommataceae are followed here.

Camposporium Harkn., Bull. South. Calif. Acad. Sci. 1: 37 (1884)

Camposporium was introduced by Harkness [51], with the single species C. antennatum. Camposporium is characterized by dematiaceous conidiophores, terminal, integrated, denticulate conidiogenous cells, and cylindrical and elongate, multiseptate conidia with one or more cylindrical appendages at the apex [52-55]. Twenty species are accepted in this genus (Species Fungorum 2020, http: / / www.speciesfungorum.org/Names/Names.asp (accessed on 13 January 2021)) and we introduced one novel Camposporium species in this paper.

Camposporium dulciaquae M.S. Calabon \& K.D. Hyde, sp. nov. (Figure 1)

MycoBank number: MB838551; Facesoffungi number: FoF 09156

Etymology: of freshwater

Holotype: MFLU 21-0015

Saprobic on submerged decaying wood in freshwater. Sexual morph: Undetermined. Asexual morph: Hyphomycetous. Colonies on natural substrate, effuse, golden brown, velvety. Mycelium mostly immersed, composed of white, septate, branched and guttulate hyphae. Conidiophores 16-95 $\times 5-9 \mu \mathrm{m}(\bar{x}=54.4 \times 6.7 \mu \mathrm{m}, n=20)$ macronematous, mononematous, often procumbent on substrate, light brown to brown, unbranched, irregularly cylindrical, flexuous, septate, thick-walled. Conidiogenous cells $9-41 \times 3-5 \mu \mathrm{m}$ $(\bar{x}=22.2 \times 4.4 \mu \mathrm{m}, n=20)$ monoblastic, terminal, integrated, subcylindrical, pale brown. Conidia 100-130 $\mu \mathrm{m}(\bar{x}=115 \mu \mathrm{m}, n=30)$ long, 8.5-13 $\mu \mathrm{m}(\bar{x}=10.7 \mu \mathrm{m}, n=30)$ wide at middle, $4-9 \mu \mathrm{m}(\bar{x}=6.1 \mu \mathrm{m}, n=30)$ wide at base, solitary, dry, cylindrical, elongate, median brown, paler at base, finely verrucose, 8-11-septate, not constricted or slightly constricted at septa, apex rounded, basal cell truncate, apical cell gives rise to (2-)3 simple appendages; appendage hyaline, aseptate, smooth, tapering from base to apex. Chlamydospores 8-18 × 5-13 $\mu \mathrm{m}(\bar{x}=12.4-9.1 \mu \mathrm{m}, n=30)$ diameter, numerous, mostly in chains, intercalary or solitary, globose to subglobose, hyaline.

Culture characteristics: Conidia germinating on malt extract agar (MEA) within $24 \mathrm{~h}$. Germ tubes produced from the basal and apical cell of conidia. Colonies growing on MEA, reaching $20 \mathrm{~mm}$ in 2 weeks at $25^{\circ} \mathrm{C}$. Mycelia superficial, circular, with entire edge, flat, rugose, from above mossy gray in the center and pale yellow at the edge, from below brown at the center then becoming yellow orange at the edge. Chlamydospores produced in culture and induced with plant tissues within 60 days. Formation of crystals in the culture was observed.

Material examined: THAILAND, Chiang Mai Province, Mushroom Research Center, on decaying wood submerged in a freshwater stream, 29 January 2019, S. Boonmee, SB14-7 (MFLU 21-0015, holotype), ex-type living culture, MFLUCC 21-0009.

GenBank accession numbers: LSU = MT860430, SSU = MW485612, ITS = MT864352, TEF1- $\alpha=$ MW537104

Notes: Camposporium dulciaquae closely resembles Camposporium septatum based on conidial morphology with 2-3 appendages and number of septa, but the former has larger conidia (100-130 $\mu \mathrm{m}$ long, $8.5-13 \mu \mathrm{m}$ wide at middle, 4-9 $\mu \mathrm{m}$ wide at base versus 98-125 $\mu \mathrm{m}$ long, 7-11.5 $\mu \mathrm{m}$ wide at middle, 3.5-6 $\mu \mathrm{m}$ wide at base). BLAST results of ITS and TEF1- $\alpha$ sequence data were C. cambrense CBS 132,486 (95\% similarity) and C. septatum 
MFLUCC 19-0483 MFLUCC 16-0274 (97\% similarity), respectively. Phylogenetic analyses of the combined LSU, SSU, ITS, and TEF1- $\alpha$ sequence dataset showed that C. dulciaquae clustered with C. septatum (MFLUCC 19-0483), Fusiconidium aquaticum (MFLUCC 16-0991 and F. mackenziei (HKAS 95019; MFLUCC 14-0434) (Figure 2). [27]. In addition, an unknown species of Camposporium (MHR 1565) isolated from a dead wood in Nan Province, Thailand grouped as a sister taxon to C. dulciaquae with high bootstrap support (95\% ML, 1.00 BYPP) [56]. The former did not have morphological data, but since comparison of its LSU sequence with the latter revealed 2 base pair differences $(0.25 \%, 794 \mathrm{bp})$, we considered this as another strain of Camposporium dulciaquae. A comparison of ITS and TEF1- $\alpha$ sequence data of C. dulciaquae differed by 19 (3.81\%, $499 \mathrm{bp})$ and $33(3.48 \%, 947 \mathrm{bp})$ base pairs with $C$. septatum, respectively. Camposporium dulciaquae had 33 (914 bp, 3.61\%) and 32 (838 bp, 3.82\%) base pair differences with F. aquaticum and F. mackenziei in TEF1- $\alpha$ region, respectively. Camposporium dulciaquae differed from Fusiconidium in conidiogenesis (monoblastic versus enteroblastic), conidial shape (cylindrical versus fusiform to ellipsoidal), and presence of apical appendage. Furthermore, C. dulciaquae fit to the description of the genus, so in this paper, we introduced a new species under Camposporium. A key to freshwater Camposporium is provided below:

1 Appendage absent C. ontariense

1 Appendage present. 2

2 Appendage branched C. japonicum

2 Appendage simple. 3

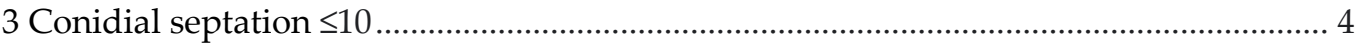

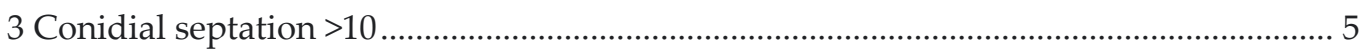

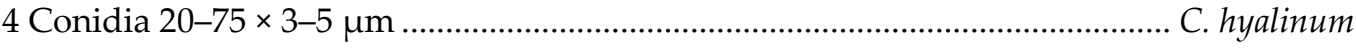

4 Conidia $28-45 \times 3.5-4.5 \mu \mathrm{m}$................................................................................. quercicola

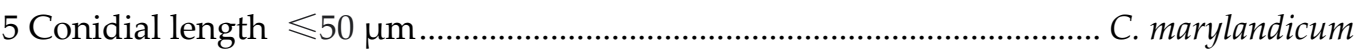

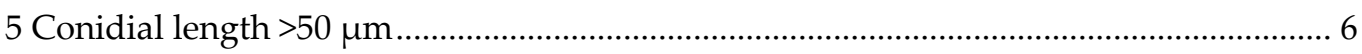

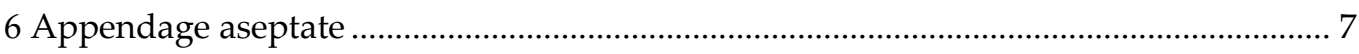

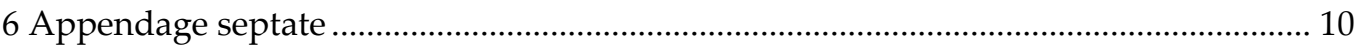

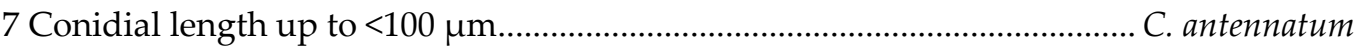

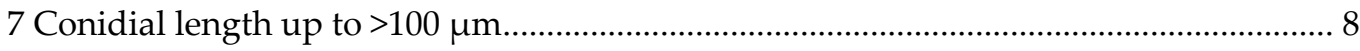

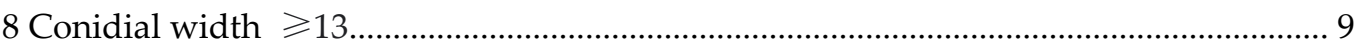

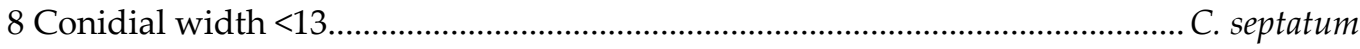

9 Conidia 100-130 × 8.5-13 $\mu \mathrm{m}$.......................................................................... dulciaquae

9 Conidia $86-115 \times 13.5-19 \mu \mathrm{m}$.................................................................... fusisporum

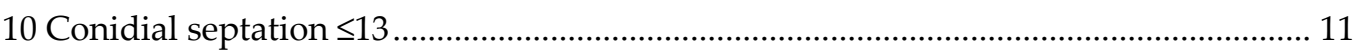

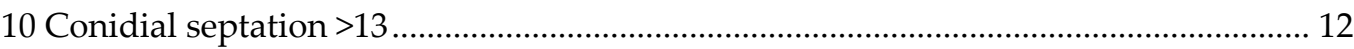

11 Conidia $107-119 \times 9.5-11.5 \mu \mathrm{m}$........................................................... . appendiculatum

11 Conidia 97-111 × 9-11 $\mu \mathrm{m}$................................................................... C. multiseptatum

12 Conidia $62-115 \times 8-10 \mu \mathrm{m}$........................................................................... C. cambrense

12 Conidia $78-140 \times 7.5-12 \mu \mathrm{m}$....................................................................... pellucidum 


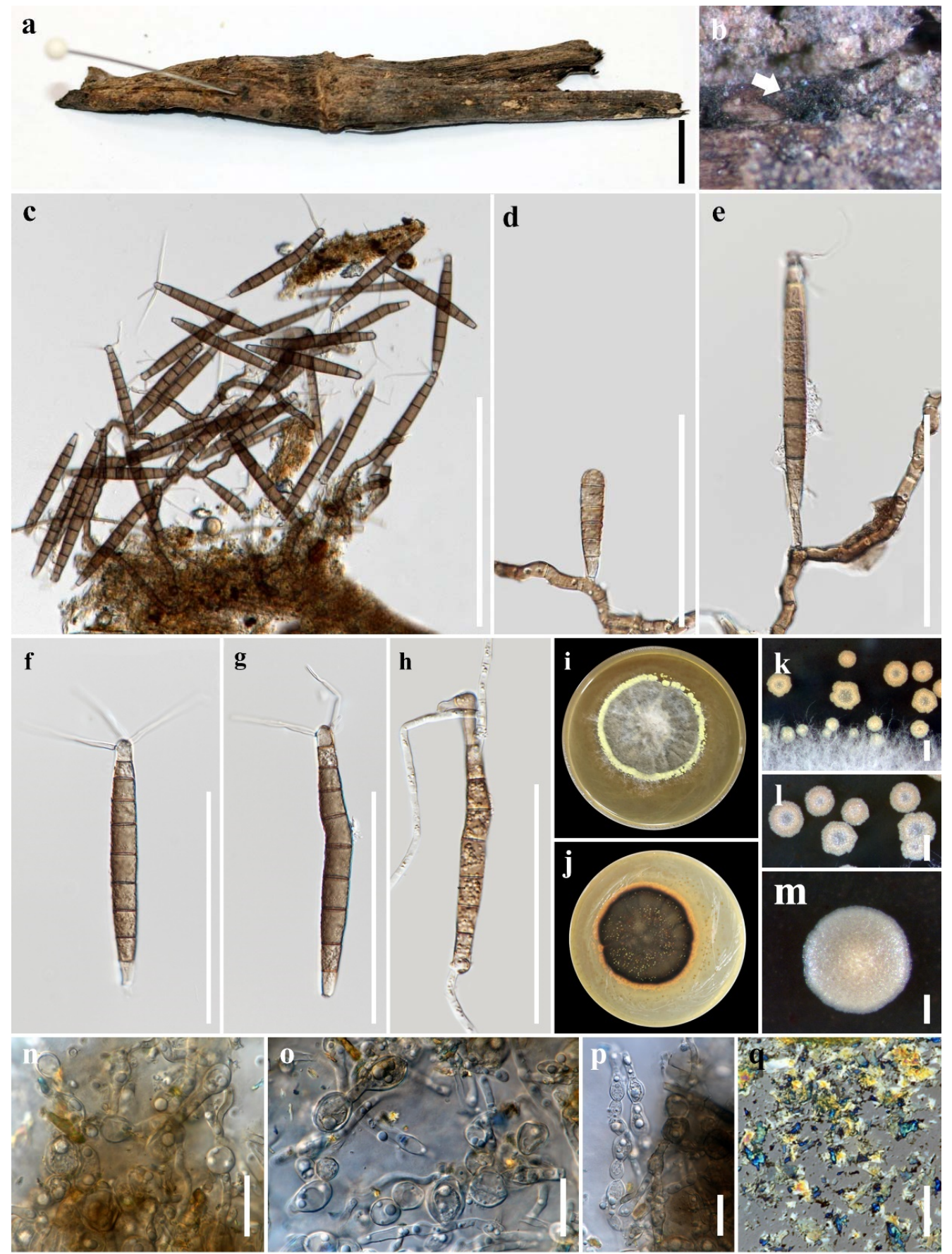

Figure 1. Camposporium dulciaquae (MFLU 21-0015, holotype). (a) Substrate; (b) colonies on wood; (c-e) conidiophores with conidia; $(\mathbf{f}, \mathbf{g})$ conidia; $(\mathbf{h})$ germinating conidium; $(\mathbf{i}, \mathbf{j})$ culture on malt extract agar (MEA) from surface and reverse; $(\mathbf{k}-\mathbf{m})$ crystals in culture; $(\mathbf{n}-\mathbf{p})$ chlamydospores; (q) crystal structure observed in microscope. Scale bars: (a,m) 10 mm; (c) $200 \mu \mathrm{m}$; (d-h) $100 \mu \mathrm{m} ;(\mathbf{k}, \mathbf{l}) 50 \mu \mathrm{m}$; (n-q) $20 \mu \mathrm{m}$. 


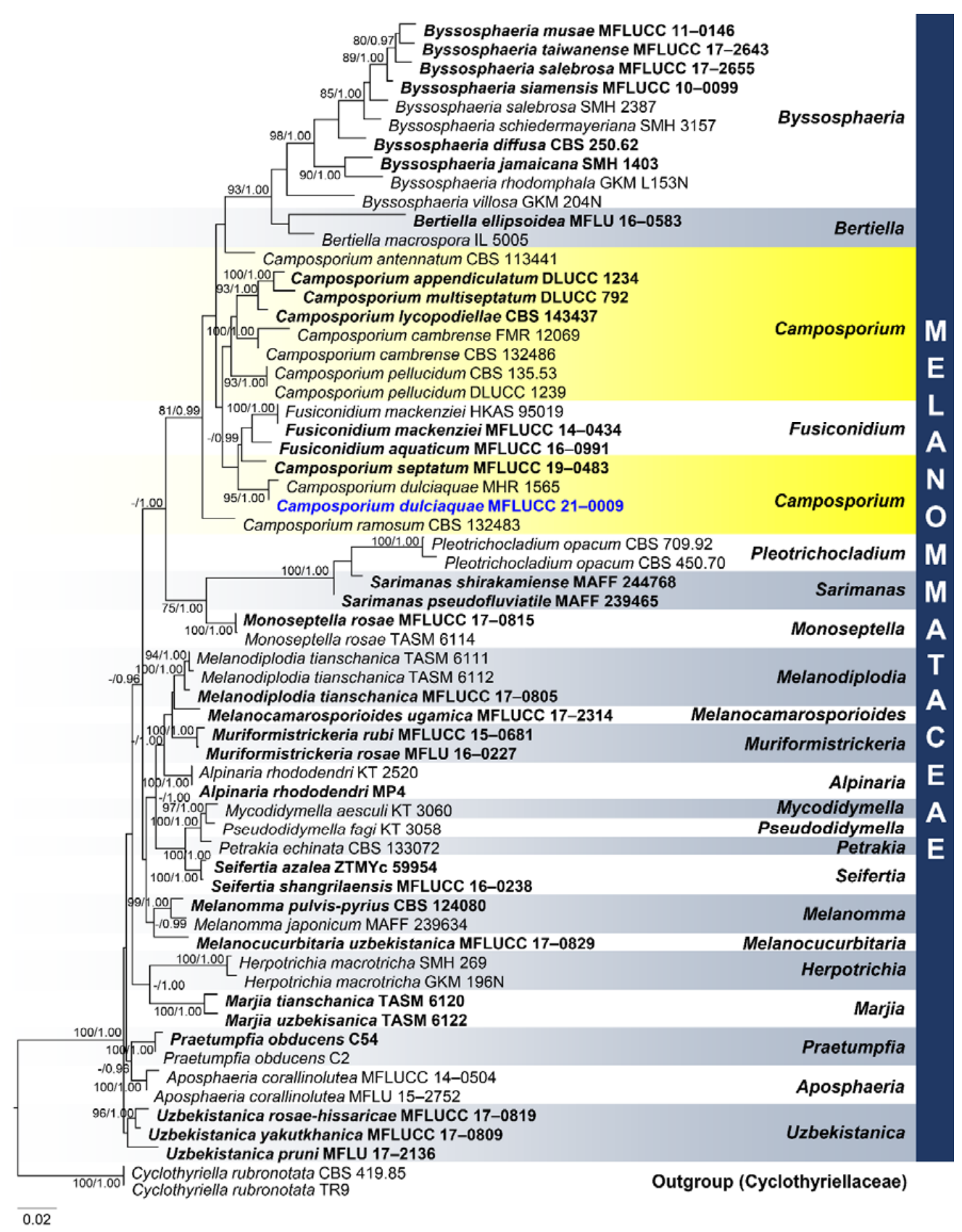

Figure 2. Phylogram generated from maximum likelihood analysis based on combined large subunit (LSU), small subunit (SSU), internal transcribed spacers (ITS), and TEF1- $\alpha$ sequence data representing the species of Melanommataceae. Related sequences are taken from Hyde et al. [57]. Sixty-two taxa were included in the combined analyses, which comprised 3433 characters (LSU = $982 \mathrm{bp}$, SSU $=963 \mathrm{bp}, \mathrm{ITS}=545 \mathrm{bp}$, TEF1- $\alpha=943$ ) after alignment. The best scoring RAxML tree with a final likelihood value of -18023.445951 is presented. The matrix had 1115 distinct alignment patterns, with $44.01 \%$ of undetermined characters or gaps. Estimated base frequencies were as follows: $\mathrm{A}=0.244338, \mathrm{C}=0.242233, \mathrm{G}=0.271538, \mathrm{~T}=0.241891$; substitution rates: $\mathrm{AC}=1.712430$, $\mathrm{AG}=2.882169, \mathrm{AT}=1.678717, \mathrm{CG}=0.989358, \mathrm{CT}=10.389868, \mathrm{GT}=1.000000$; gamma distribution shape parameter $\alpha=0.154096$. Bootstrap support values for $\mathrm{ML}$ equal to or greater than $75 \%$ and BYPP equal to or greater than 0.95 are given above the nodes. Cyclothyriella rubronotata (CBS 419.85; TR9) in Cyclothyriellaceae were used as the outgroup taxa. The newly generated sequence is indicated in blue. The ex-type strains are indicated in bold. 
Occultibambusaceae D.Q. Dai \& K.D. Hyde

Dai et al. [58] introduced Occultibambusaceae to accommodate Neooccultibambusa, Occultibambusa, Seriascoma and Versicolorisporium. Brunneofusispora, typified by Brunneofusispora sinensis, was introduced by Phookamsak et al. [59] as a new member of the family. The latest treatment of the family follows Hongsanan et al. [15] and Wijayawardene et al. [49] with 5 accepted genera in Occultibambusaceae.

Brunneofusispora S.K. Huang \& K.D. Hyde, Fungal Diversity 95: 36 (2019)

Brunneofusispora, typified by B. sinensis, was introduced by Phookamsak et al. [59]. Hongsanan et al. [15] discussed the key differences of Brunneofusispora to other genera in Occultibambusaceae and Wanasinghe et al. [60] observed the coelomycetous asexual morph of $B$. sinensis and amended the generic and species description. Two species, B. sinensis and B. clematidis, have molecular data and are accepted in this genus (Species Fungorum 2020; http://www.speciesfungorum.org/Names/Names.asp (accessed on 13 January 2021)). Brunneofusispora sinensis was described from undetermined terrestrial wood near in a river [59] and Magnolia denudata [60] in China, while B. clematidis was observed in Clematis subumbellata by Phukhamsakda et al. [61]. In this paper, one novel coelomycetous Brunneofusispora species from a freshwater habitat is introduced.

Brunneofusispora hyalina M.S. Calabon \& K.D. Hyde, sp. nov. (Figure 3)

MycoBank number: MB838552; Facesoffungi number: FoF 09531

Etymology: refers to hyaline conidia

Holotype: MFLU 21-0016

Saprobic on decaying wood submerged in freshwater habitats. Sexual morph: Undetermined. Asexual morph: Mycelium mostly immersed, composed of septate, branched, hyphae. Conidiomata $260-435 \times 110-205 \mu \mathrm{m}(\bar{x}=347 \times 175 \mu \mathrm{m}, n=10)$, black, pycnidial, solitary, immersed to semi-immersed, globose to subglobose, ostiolate. Ostiole circular, papillate, laterally or centrically located. Conidiomatal wall $10-20 \mu \mathrm{m}$ wide $(\bar{x}=16 \mu \mathrm{m}$, $n=15$ ), composed of thick-walled, dark brown to hyaline cells of textura angularis. Conidiophores reduced to conidiogenous cells. Conidiogenous cells 5-11 $\mu \mathrm{m} \times 2-4 \mu \mathrm{m}(\bar{x}=8 \mu \mathrm{m}$, $n=20$ ), hyaline, thin-walled, enteroblastic, phialidic, smooth, cylindrical, subcylindrical, ampulliform, pyriform, swollen at base, discrete, producing a single conidium at apex. Conidia $2-4 \times 1.3-2.6 \mu \mathrm{m}(\bar{x}=2.7 \times 1.9 \mu \mathrm{m}, \mathrm{n}=50)$, aseptate, oblong, cylindrical to ovoid, tapered to apices, hyaline, smooth-walled.

Culture characteristics: Conidia germinating on malt extract agar (MEA) within $24 \mathrm{~h}$. Germ tubes produced from the basal and apical cells of the conidia. Colonies growing on MEA, reaching $40-45 \mathrm{~mm}$ in 4 weeks at $25{ }^{\circ} \mathrm{C}$. Mycelia superficial, circular, with entire margin, flat, smooth, from above brown at the center, dark brown at the edge, from below dark brown.

Material examined: THAILAND, Chiang Mai Province, Mushroom Research Center (MRC), on decaying wood submerged in a stream, 13 September 2019, M.S. Calabon, WF03 (MFLU 21-0016, holotype), ex-type living culture, MFLUCC 21-0008.

GenBank accession numbers: LSU $=$ MT860430, SSU $=$ MW485613, ITS $=$ MT864352, TEF1- $\alpha=$ MW512606, RPB2 = MW512609

Notes: Based on morphology, coupled with multi-loci phylogenetic analyses, the novel taxon was placed in Brunneofusispora. Brunneofusispora hyalina is similar to B. sinensis in conidiogenesis and conidial shape but differs in the size of conidiomata (260-435 $\times 110-205 \mu \mathrm{m}$ diameter versus 120-160 $\mu \mathrm{m} \times 80-120 \mu \mathrm{m}$ diameter) and conidiogenous cells (5-11 $\mu \mathrm{m} \times 2-4 \mu \mathrm{m}$ versus 6-7.5 $\mu \mathrm{m} \times 2.5-3 \mu \mathrm{m}$ ) [60]. In the phylogenetic analysis, Brunneofusispora hyalina clustered as a sister taxon to Brunneofusispora sp. (X135) (Figure 4). The latter is named in GenBank as Neooccultibambusa sp. with an accession number MK304223 for the ITS gene region but there are no available description and photographic plate for this species, so we transferred this to Brunneofusispora. BLAST results of ITS and LSU sequence data were Pleosporales sp. E69101 (99\% similarity) and Neooccultibambusa thailandensis MFLUCC 
16-0274 (98\% similarity), respectively. The TEF1- $\alpha$ sequence was $95 \%$ similar to Brunneofusispora sinensis (KUMCC 17-0030), Occultibambusa fusispora (MFLUCC 11-0127), and Occultibambusa bambusae (MFLUCC 13-0855), while RPB2 sequence data were $85.19 \%$ similar to Occultibambusa fusispora MFLUCC 11-0127. Brunneofusispora hyalina had 35 base pair differences (493 bp, 7.10\%) in the ITS region when compared to Brunneofusispora sp. (X135). A comparison of ITS and TEF1- $\alpha$ sequence data of B. hyalina differed by $49(9.25 \%, 530 \mathrm{bp})$ and $37(6.41 \%, 577 \mathrm{bp})$ base pairs with B. clematidis, respectively. Brunneofusispora hyalina differed by $41(7.87 \%, 521 \mathrm{bp})$ and 44 base pairs $(4.73 \%, 931 \mathrm{bp})$ in ITS and TEF1- $\alpha$ sequence data, respectively, when compared to B. sinensis (MFLUCC 17-2070).

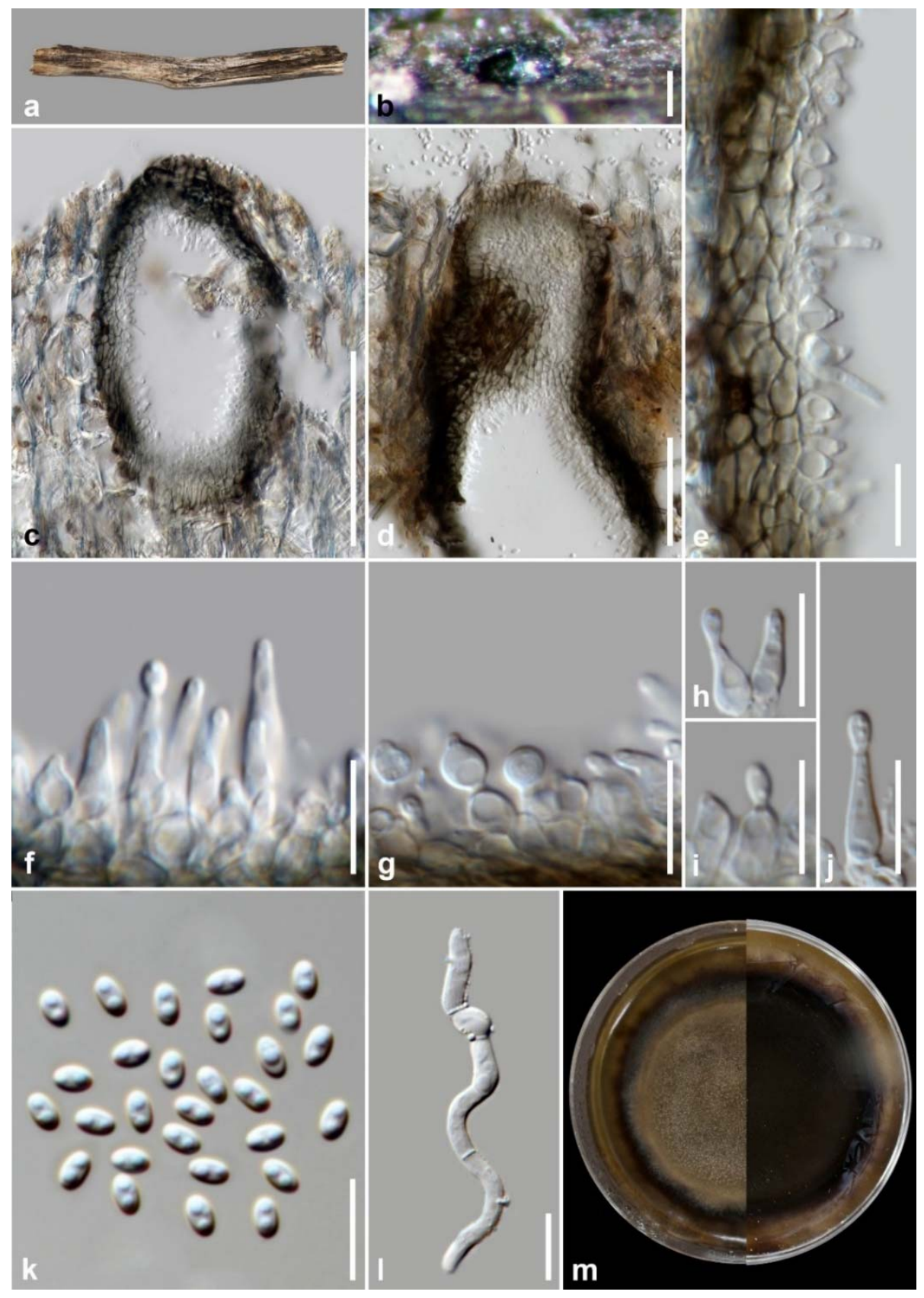

Figure 3. Brunneofusispora hyalina (MFLU 21-0016, holotype). (a) Host; (b) black conidiomata on the host; (c,d) vertical section of conidiomata; (e) vertical section of conidiomatal wall.; $(\mathbf{f}-\mathbf{j})$ conidiogenous cells and developing conidia; (k) conidia; (l) germinated conidium; (m) culture on MEA. Scale bars: (b,c) $100 \mu \mathrm{m}$; (d) $50 \mu \mathrm{m}$; (e-1) $10 \mu \mathrm{m}$. 


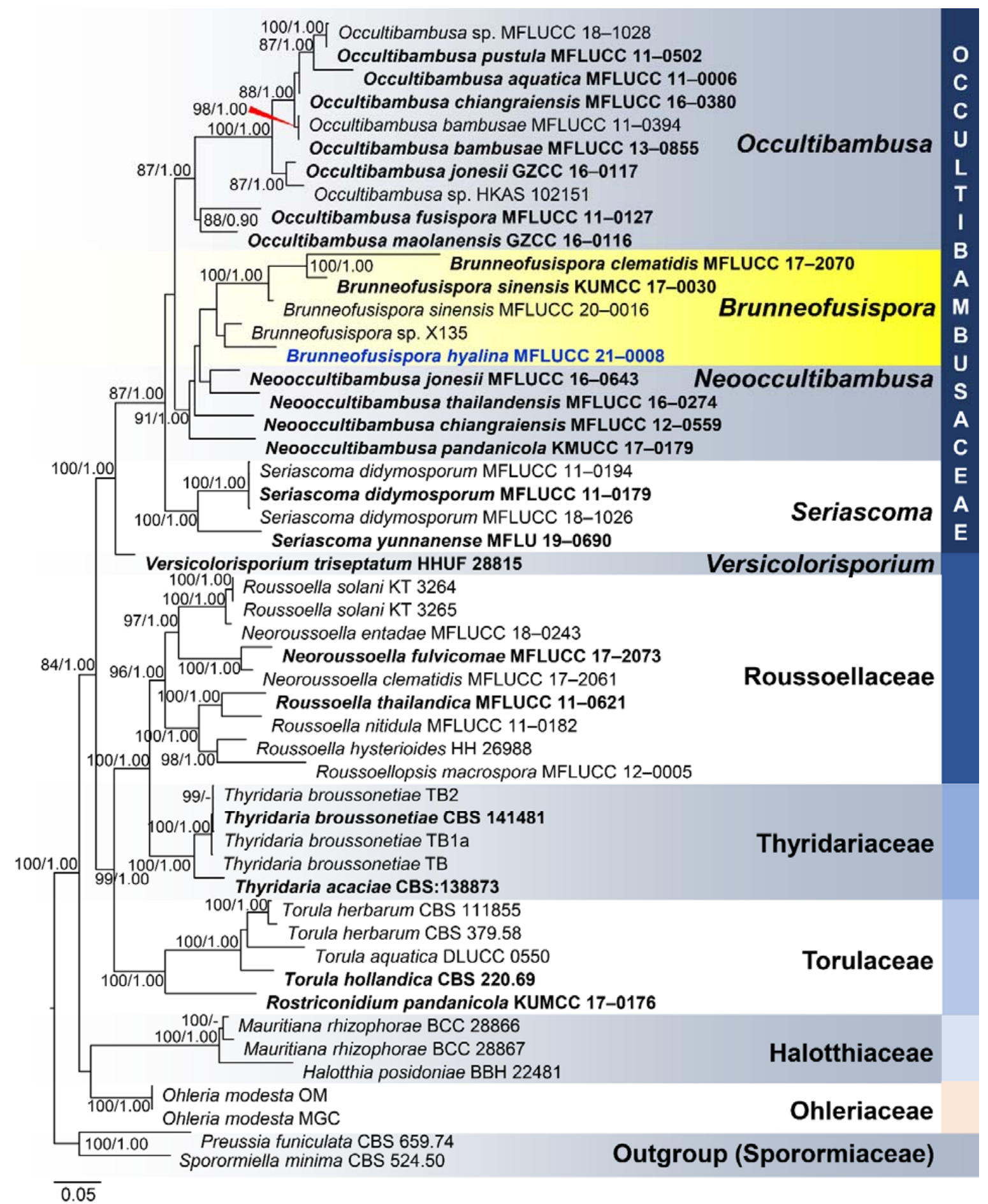

Figure 4. Phylogram generated from maximum likelihood analysis based on combined LSU, SSU, ITS, TEF1- $\alpha$, and RPB2 sequence data representing the species of Pleosporales. Related sequences are taken from Tibpromma et al. [62]. Fifty taxa were included in the combined analyses, which comprised 6314 characters (LSU $=1116$, SSU $=988$, ITS $=2438, T E F 1-\alpha=678$, $R P B 2=1094)$ after alignment. The best scoring RAxML tree with a final likelihood value of -22606.054905 is presented. The matrix had 2273 distinct alignment patterns, with $50.65 \%$ of undetermined characters or gaps. Estimated base frequencies were as follows: $\mathrm{A}=0.249087, \mathrm{C}=0.252571, \mathrm{G}=0.272240, \mathrm{~T}=0.226102$; substitution rates: $\mathrm{AC}=1.279443, \mathrm{AG}=3.002197$, $\mathrm{AT}=1.311809, \mathrm{CG}=1.122167, \mathrm{CT}=6.076550, \mathrm{GT}=1.000000$; gamma distribution shape parameter $\alpha=0.234175$. Bootstrap support values for ML equal to or greater than 75\% and BYPP equal to or greater than 0.95 are given above the nodes. Preussia funiculata CBS 659.74 and Sporormiella minima CBS 524.50 in Sporormiaceae were used as the outgroup taxa. The newly generated sequence is indicated in blue. The ex-type strains are indicated in bold. 


\subsubsection{Sordariomycetes O.E. Erikss. et Winka, Myconet 1: 10 (1997)}

The latest treatment of Sordariomycetes by Hyde et al. [16] is followed with 45 orders, 167 families and 1499 genera (with 308 genera incertae sedis) listed and described. Three new species of freshwater Sordariomycetes are introduced and described in this paper.

Chaetosphaeriales Huhndorf, A.N. Mill. \& F.A. Fernández, Mycologia 96(2): 378 (2004)

Chaetosphaeriales was introduced by Huhndorf et al. [63]. The order comprises five families (Chaetosphaeriaceae, Helminthosphaeriaceae, Leptosporellaceae, Leptosporellaceae, and Linocarpaceae) with 55 genera recorded [49]. Sixty-nine species were recorded from freshwater habitats (Chaetosphaeriaceae: 59, Helminthosphaeriaceae: 6, Linocarpaceae: 4) [10].

Chaetosphaeriaceae Réblová, M.E. Barr \& Samuels, Sydowia 51(1): 56 (1999)

Forty-four genera constitute Chaetosphaeriaceae, wherein 12 genera (59 species) were recorded in freshwater habitats $[10,49,64]$. Freshwater Dictyochaeta is the most speciose genus in the family with 16 species recorded [10].

Rattania Prabhugaonkar \& Bhat, Mycotaxon 108: 218 (2009)

Rattania was introduced by Prabhugaonkar and Bhat [65] to accommodates Rattania setulifera, a species isolated from fresh leaves of rattan (Calamus thwaitesii) in India. Shenoy et al. [66] placed the genus in Chaetosphaeriales. Rattania is characterized by sporodochial, setose conidiomata, monoblastic conidiogenous cells and slimy, fusiform, 0-5-septate, setulate conidia [65]. In this paper, a new Rattania species observed from submerged decaying wood in freshwater river in Thailand is introduced.

Rattania aquatica M.S. Calabon \& K.D. Hyde, sp. nov. (Figure 5)

MycoBank number: MB838553; Facesoffungi number: FoF 09532

Etymology: in reference to the habitat where the fungus was collected

Holotype: MFLU 21-0013

Saprobic on decaying wood submerged in freshwater habitats. Sexual morph: Undetermined. Asexual morph: Colonies on the substrate effuse, scattered, dark brown to black. Mycelium mostly immersed, composed of branched, septate, smooth, thin-walled, brown hyphae. Conidiomata $170-270 \times 55-150 \mu \mathrm{m}(\bar{x}=210 \mu \mathrm{m}, n=10)$, superficial, synnematous, scattered, dark brown to black, funnel-shaped, sessile sporodochia with spore mass at the apex. Setae 290-475 $\times 3-14 \mu \mathrm{m}(\bar{x}=340 \times 9, n=10)$, erect, straight to curved, flexuous, unbranched, irregular in length, cylindrical, tapering towards apex into an acute tip, 10-15 septate, smooth, thick-walled. Conidiophores up to $175 \mu \mathrm{m}$ long, macronematous, brown, cylindrical, densely compacted along the synnematal axis, smooth-walled. Conidiogenous cells $2-4 \mu \mathrm{m}$ long $(\bar{x}=2.8 \mu \mathrm{m}, n=10)$, terminal, integrated or discrete, hyaline, smooth-walled. Conidia 22-27 $\times 3-5 \mu \mathrm{m}(\bar{x}=24.9 \times 3.9 \mu \mathrm{m}, n=30)$, hyaline, naviculate to fusiform, apex acute, base truncate, smooth, thin-walled, $0-1$ septate, mostly aseptate, with a single filiform setula at both ends, 3.6-8.3 $\mu \mathrm{m}$ long, guttulate.

Culture characteristics: Conidia germinating on malt extract agar (MEA) within $24 \mathrm{~h}$. Germ tubes produced from the basal and apical cell of conidia. Colonies growing on MEA, reaching $30-35 \mathrm{~mm}$ in 2 weeks at $25^{\circ} \mathrm{C}$. Mycelia superficial, circular, with entire margin, flat, smooth, from above white, from below white.

Material examined: THAILAND, Tak Province, Tha Sing Yang, Ban Mae Ja Wang on decaying wood submerged in a freshwater river, 17 October 2019, N. Padaruth, CC24 (MFLU 21-0013, holotype), ex-type living culture, MFLUCC 21-0006.

GenBank accession numbers: LSU = MW287235; ITS = MW260331

Notes: Rattania aquatica differs from the type species $R$. setulifera in conidiomatal morphology (synnemata versus sporodochia), shorter conidia $(22-27 \times 3-5 \mu \mathrm{m}$ versus 5-50 um $\times 1.5-3.5)$ and conidial septation (0-1 versus 0-5) [65]. Based on the BLASTn search of ITS sequence data in GenBank, the closest matches are Chaetosphaeriaceae sp. TBA274 (96\%) and Sordariomycetes sp. KO-2013 (95\%). However, Rattania setulifera (GUFCC 15501) is the closest match for the LSU sequence data with $98 \%$ similarity. 
The multi-loci phylogenetic analyses show that $R$. aquatica is a distinct species and sister taxon to $R$. setulifera (GUFCC 15501) with 95\% MP, 1.00 BYPP support (Figure 6). A comparison of ITS and LSU sequence data between $R$. aquatica and $R$. setulifera revealed $9.68 \%$ (46/475 bp) and $2.20 \%$ (18/820 bp) nucleotide base pair differences, respectively.

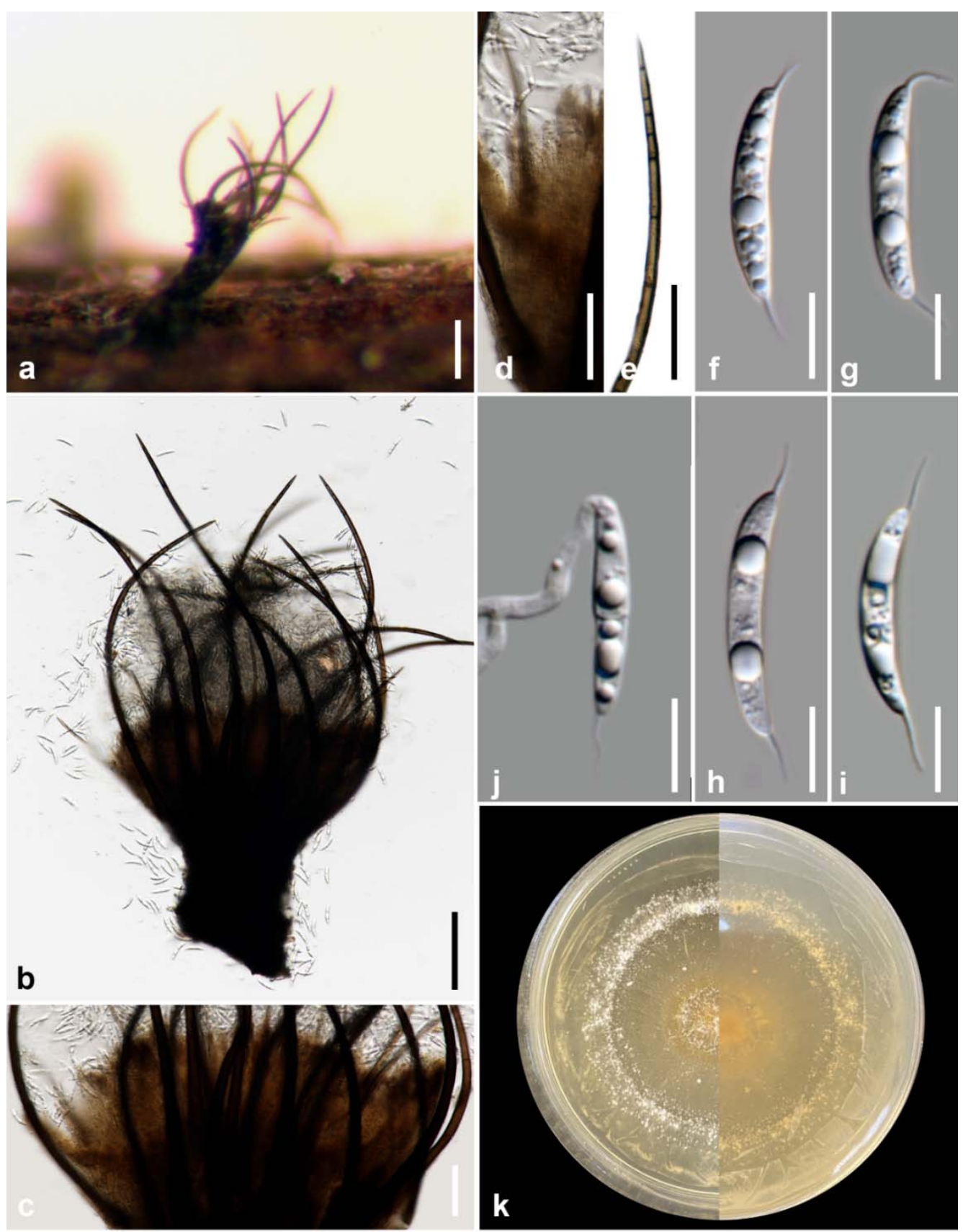

Figure 5. Rattania aquatica (MFLU 21-0013, holotype). (a) Appearance of conidioma on host; (b) synnemata; (c,d) closely packed conidiophores; (e) setae; (f-i). conidia; (j) germinated conidium; (k) culture on MEA. Scale bars: (a,b) $100 \mu \mathrm{m}$; (c-e) $50 \mu \mathrm{m} ;(\mathbf{f}-\mathbf{j}) 10 \mu \mathrm{m}$. 


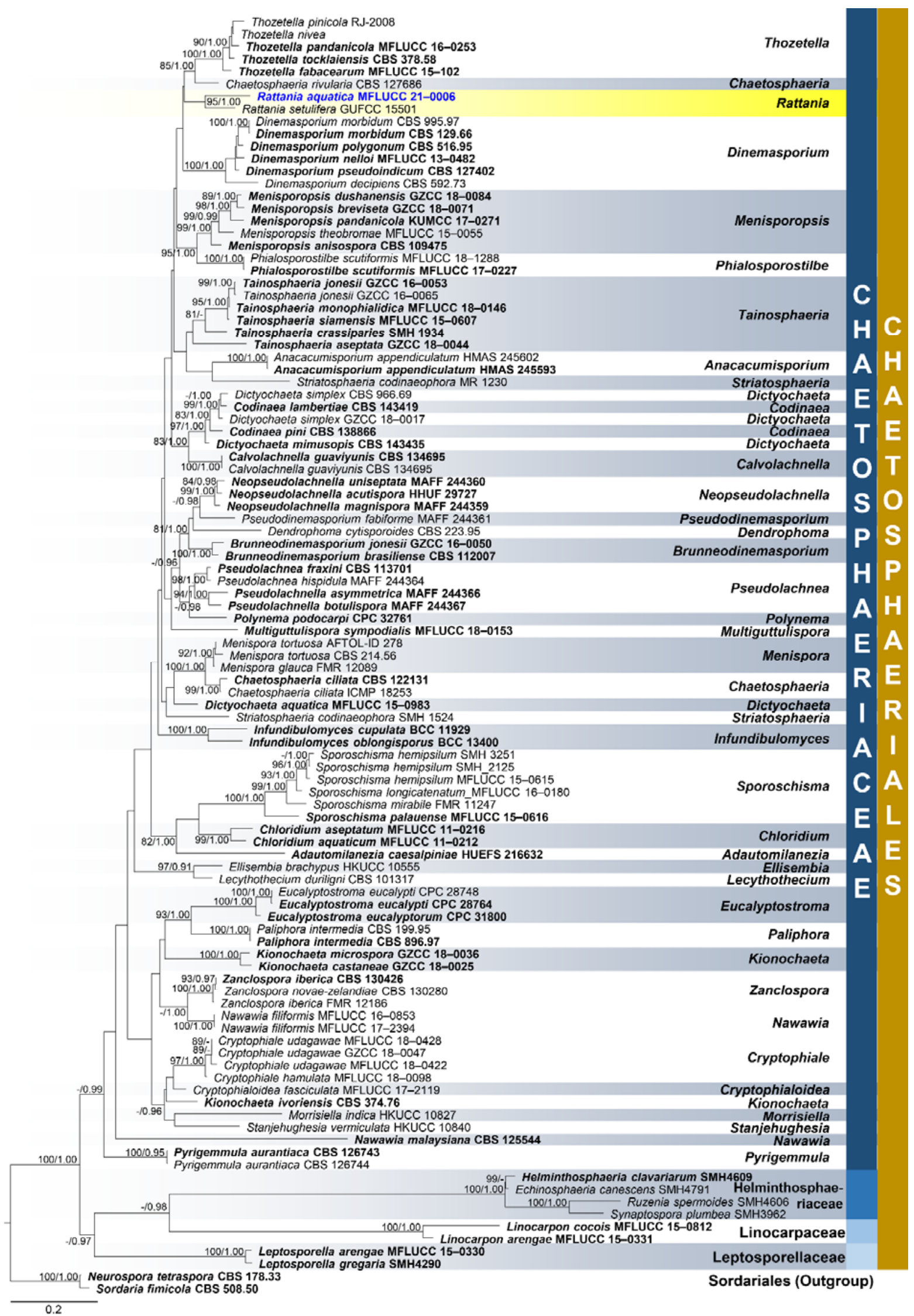

Figure 6. Phylogenetic tree generated from maximum likelihood (ML) analysis based on combined LSU and ITS sequence data for the species from Chaetosphaeriales. Related sequences are taken from Lin et al. [64]. One-hundred three taxa were 
included in the combined analyses which comprised 1329 characters after alignment including gaps. LSU: 789 bp, ITS: $540 \mathrm{bp}$. The RAxML analysis of the combined dataset yielded a best scoring tree with a final ML optimization likelihood value of $-19,119.372669$. The matrix had 730 distinct alignment patterns, with $13.78 \%$ undetermined characters or gaps. Estimated base frequencies were as follows: $\mathrm{A}=0.225668, \mathrm{C}=0.269306, \mathrm{G}=0.309464, \mathrm{~T}=0.195562$; substitution rates $\mathrm{AC}=1.438984, \mathrm{AG}=1.899345, \mathrm{AT}=1.390083, \mathrm{CG}=0.832127, \mathrm{CT}=6.028381, \mathrm{GT}=1.000000$; gamma distribution shape parameter $\alpha=0.286425$. Bootstrap support values for ML equal to or greater than $75 \%$ and BYPP equal to or greater than 0.95 are given above the nodes. Neurospora tetraspora (CBS 178.33) and Sordaria fimicola (CBS 508.50) from Sordariales were used as outgroup taxa. The newly generated sequence is indicated in blue. The ex-type strains are indicated in bold.

Phyllachorales M.E. Barr, Mycologia 75: 11 (1983)

Phyllachorales was formally described by Barr [67] but phyllachoraceous taxa were placed by several authors in various orders and families (see [68] for historical placement of phyllachoraceous fungi). Four families (Phaeochoraceae, Phaeochorellaceae, Phyllachoraceae, Telimenaceae) and 60 genera were included in Phyllachorales [49]. The divergence time for the order is estimated as 168 MYA (Hyde et al. 2020). Phyllachoraceous taxa are biotrophic, obligate plant parasitic fungi, and saprobic on palms (Arecaceae) and submerged decaying wood [16].

Phyllachorales Genera incertae sedis

Wijayawardene et al. (2020) listed Marinosphaera under Phyllachorales genera incertae sedis. In this paper, a novel genus is introduced based on morphology and multi-loci phylogenetic analyses.

Neoxylomyces M.S. Calabon, Boonmee, E.B.G. Jones \& K.D. Hyde, gen. nov.

MycoBank number: MB838554; Facesoffungi number: FoF 09533

Etymology: referring to the similarity to the genus Xylomyces

Saprobic on decaying wood submerged in freshwater habitats. Sexual morph: Undetermined. Asexual morph: Colonies on the substrate effuse, scattered, dark brown to black. Mycelium mostly immersed, composed of branched, septate, smooth, thin-walled, dematiaceous, anastomosing hyphae. Conidiophores and conidia not developed. Chlamydospores narrowly fusiform, cylindrical, intercalary, erect, mostly straight, slightly curved, solitary or in chains, occasionally branched, multiseptate, constricted at septa, brown, paler end cells, thick-walled with scarce irregular longitudinal striations.

Type species: Neoxylomyces multiseptatus M.S. Calabon, Boonmee, E.B.G. Jones \& K.D. Hyde

Notes: Neoxylomyces is similar to Xylomyces in having brown, thick-walled, multiseptate chlamydospores $[14,48]$. The latter, typified by X. chlamydosporus, is placed in Aliquandostipitaceae while Neoxylomyces clustered with other taxa of Phyllachorales with 100\% ML, 1.00 BYPP support (Figure 7). In multi-loci phylogenetic analyses, Neoxylomyces shared the same clade with Clathrosporium retortum (CCIBt 4122; CCIBt 4123) with 100\% ML, 1.00 BYPP support.

Neoxylomyces multiseptatus MS Calabon, Boonmee, E.B.G. Jones \& K.D. Hyde, sp. nov. (Figure 8)

MycoBank number: MB838555; Facesoffungi number: FoF 09534

Etymology: In reference to the multiseptate chlamydospores

Holotype: MFLU 21-0014

Saprobic on decaying wood submerged in freshwater habitats. Sexual morph: Undetermined. Asexual morph: Colonies on the substrate effuse, scattered, dark brown to black. Mycelium mostly immersed, composed of branched, septate, smooth, thin-walled, dematiaceous, anastomosing hyphae. Conidiophores and conidia not developed. Chlamydospores $111-378 \times 8-13 \mu \mathrm{m}(\bar{x}=255 \times 10.2 \mu \mathrm{m}, n=30)$, narrowly fusiform, cylindrical, intercalary, erect, mostly straight, slightly curved, solitary or in chains, occasionally 
branched, with 7-45 septa, constricted at septa, brown, paler and truncated end cells, $3.28-5.93 \mu \mathrm{m}$ wide $(\bar{x}=4.39 \mu \mathrm{m})$, thick-walled with scarce irregular longitudinal striations.

Culture characteristics: Chlamydospores germinating on malt extract agar (MEA) within $24 \mathrm{~h}$. Germ tubes produced from the basal and apical cell of conidia. Colonies growing on MEA, reaching $35-40 \mathrm{~mm}$ in 4 weeks at $25^{\circ} \mathrm{C}$. Mycelia superficial, circular, with entire margin, flat, smooth, from above ivory to pale brown at the margin, white at the center; reverse, dark brown at the center then becoming pale orange to light brown at the margin.

Material examined: THAILAND, Chiang Mai Province, Mae Teang District, Mushroom Research Center (M.R.C.), on decaying wood submerged in a stream, 11 February 2019, M.S. Calabon, MC02 (MFLU 21-0014, holotype), ex-type living culture, MFLUCC 21-0007.

GenBank accession numbers: LSU = MW287236, SSU = MW287239, ITS = MW260332, TEF1- $\alpha=$ MW512607

Notes: Neoxylomyces multiseptatus is similar to Xylomyces giganteus in having brown, long, multiseptate chlamydospores. The former differs in the number of septa (7-45 versus 6-85), size of the chlamydospores (111-378 × 8-13 $\mu \mathrm{m}$ versus (140) $190-575 \times 25-50 \mu \mathrm{m}$ ), and absence of a mucilaginous coating to the chlamydospores [69,70]. Furthermore, Xylomyces belongs to Aliquandostipitaceae (Jahnulales, Dothideomycetes) [49]. The closest match of the sequences based on BLASTn searches in NCBI GenBank database were Clathrosporium. Clathrosporium retortum (CCIBt 4123) was the closest species based on BLAST result of ITS ( $83 \%$ similarity) and LSU sequence data (95\% similarity). The TEF1$\alpha$ sequence was $91 \%$ similar to Tolypocladium ophioglossoides (NBRC:8992), T. paradoxum (NBRC:106958), Metarhizium granulomatis (UAMH 11176), and Hypomyces polyporinus (ATCC 76479). The multi-loci phylogenetic analyses show that N. multiseptatus is a distinct species and sister taxon to Clathrosporium retortum (CCIBt 4123) with 100\% MP, $1.00 \mathrm{BYPP}$ support. The former has long, narrowly fusiform, multiseptate chlamydospores while the latter has subglobose to irregular, hyaline to subhyaline conidia formed by branched, densely interwoven conidial filaments [71].

Togniniales Senan., Maharachch. \& K.D. Hyde, Fungal Diversity 72: 220 (2015)

Maharachchikumbura et al. [74] introduced Togniniales to accommodate Togniniaceae based on multi-loci phylogenetic analyses. The monotypic order is characterized by perithecial ascomata and clavate, tiny asci with hyaline ascogenous hyphae, and cylindrical to allantoid ascospores [74,75]. Hyde et al. [16] estimated the divergence of the order as 138 MYA.

Togniniaceae Réblová, L. Mostert, W. Gams \& Crous, Stud. Mycol. 50(2): 540 (2004)

Réblová et al. [76] introduced Togniniaceae based on LSU and SSU sequence data of Togninia species. Togniniaceae has been referred to various orders Calosphaeriales [77] and Diaporthales [78], but Maharachchikumbura et al. [74] excluded it from Diaporthales and accommodated Togniniaceae in Togniniales. Two genera, Conidiotheca and Phaeoacremonium, constitute the family.

Phaeoacremonium W. Gams, Crous \& M.J. Wingf., Mycologia 88: 789 (1996)

Crous et al. [79] introduced Phaeoacremonium (=Togninia), with P. parasiticum as the type species. Phaeoacremonium was known to be the asexual morph of Togninia, a genus introduced by Berlese (1990) with T. minima as the type species. Togninia was synonymized under Phaeoacremonium by Gramaje et al. [80] as the latter has the most species, widely used by mycologist, and some Togninia species already have names in Phaeoacremonium. Sixty-seven epithets of Phaeoacremonium are listed in Species Fungorum (2020; http:/ / www. speciesfungorum.org/Names/Names.asp (accessed on 13 January 2021)).

Phaeoacremonium thailandense M.S. Calabon \& K.D. Hyde, sp. nov. (Figure 9)

Mycobank number: MB838556; Facesoffungi number: FoF 09535

Etymology: In reference to the host location, Thailand, where the holotype was collected.

Holotype: MFLU 21-0012 
Saprobic on decaying wood submerged in freshwater habitats. Sexual morph: Ascomata $170-280 \mu \mathrm{m}(\bar{x}=212 \mu \mathrm{m}, n=10)$ diameter, perithecial, scattered to gregarious, immersed to semi-immersed, globose to subglobose, black, coriaceous. Ascomatal wall $15-45 \mu \mathrm{m}$ thick ( $\bar{x}=28 \mu \mathrm{m}, n=10)$, membranous, comprising $8-10$ layers, of outer dark brown to brown and inner hyaline cells of textura angularis. Hamathecium composed of 2-7 $\mu \mathrm{m}(\bar{x}=3.9 \mu \mathrm{m}, n=10)$ wide, hyaline, septate paraphyses, slightly constricted at septa and gradually narrowed towards apex, longer than asci. Asci 18-25 $\times 4-6 \mu \mathrm{m}(\bar{x}=22 \times 5$, $n=20), 8$-spored, unitunicate, clavate, apex truncate, apedicellate, with truncate bases. Ascogenous hyphae hyaline, septate, simple, smooth-walled, 2-3 $\mu \mathrm{m}$ at base. Ascospores 4.8-6.6 $\times 1.2-1.6 \mu \mathrm{m}(\bar{x}=5.7 \times 1.4 \mu \mathrm{m}, n=30)$, biseriate, reniform with rounded ends, unicellular, hyaline, thin-walled, smooth-walled, often containing small guttules at both ends. Asexual morph: Undetermined.

Material examined: THAILAND, Tak Province, Tha Sing Yang, Ban Mae Ja Wang, on decaying wood submerged in a freshwater river, 17 October 2019, N. Padaruth, CC12 (MFLU 21-0012, holotype), ex-type living culture, MFLUCC 21-0005.

Culture characteristics: Ascospores germinating on malt extract agar (MEA) within $24 \mathrm{~h}$. Germ tubes produced from the basal and apical cell of conidia. Colonies growing on MEA, reaching 20-25 mm in 2 weeks at $25^{\circ} \mathrm{C}$. Mycelia superficial, circular, with entire margin, flat, smooth, transparent, spare, from above light brown; reverse, light brown.

GenBank numbers: LSU $=$ MW287238, ITS $=$ MW260334, TEF1- $\alpha=$ MW512608, TUB2 = MW512610, ACT $=$ MW512611

Notes: Phaeoacremonium thailandense shares the same morphology with other sexual morphs of the genus, such as ascus formation in acropetal succession, ascal apex thickened without a discharge mechanism, hyaline ascogenous hyphae, and allantoid, reniform to oblong-cylindrical ascospores [16]. Currently, three species of Phaeoacremonium are reported in freshwater habitats: P. aquaticum, P. ovale, and P. thailandense [10]. The novel species differs from P. aquaticum and P. ovale in the absence of an ostiolar neck, and longer asci (18-25 $\mu \mathrm{m}$ versus $18-21 \mu \mathrm{m}$ versus $11-20 \mu \mathrm{m})$ [81,82]. The closest match of the sequences based on BLASTn searches in GenBank is Phaeoacremonium. Phaeoacremonium sicilianum (CBS 123034) is the closest species based on BLAST result of ITS region with $92 \%$ similarity. The TEF1- $\alpha$ sequence was $94 \%$ similar to P. minimum strains (AFTOL-ID 924; UCRPA7), while TUB sequence was $80 \%$ similar to P. silicianum strains (KER-U-PMS4; KER-U-PMS5; KER-U-PMS6). The multi-loci phylogenetic analyses showed that $P$. thailandense is a distinct species and sister taxon to P. silicianum strains (CBS 123034; 123035) with $100 \% \mathrm{MP}$, 1.00 BYPP support (Figure 10). A comparison of ITS and ACT sequence data between P. thailandense and P. silicianum revealed $17.45 \%$ (41/235 bp) and $6.46 \%(39 / 604 \mathrm{bp})$ nucleotide base pair differences, respectively. 


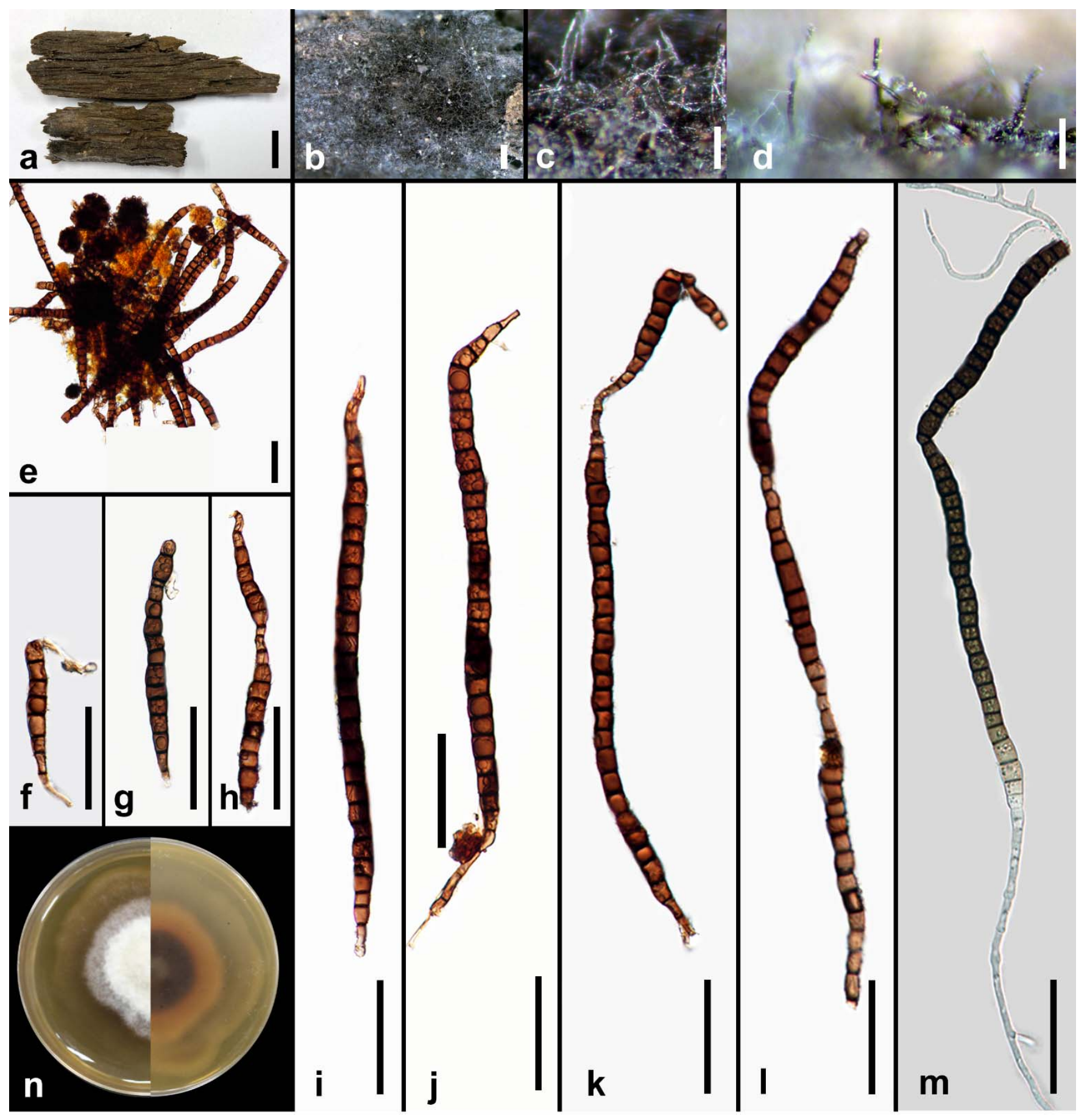

Figure 7. Neoxylomyces multiseptatus (MFLU 21-0014, holotype). (a) Host; (b-e) colonies on wood; (f-1) chlamydospores; (m) germinated chlamydospore; (n) culture on MEA. Scale bars: (a) 10 mm; (b,c) $500 \mu \mathrm{m}$; (d) $100 \mu \mathrm{m} ;(\mathbf{e}-\mathbf{m}) 50 \mu \mathrm{m}$. 


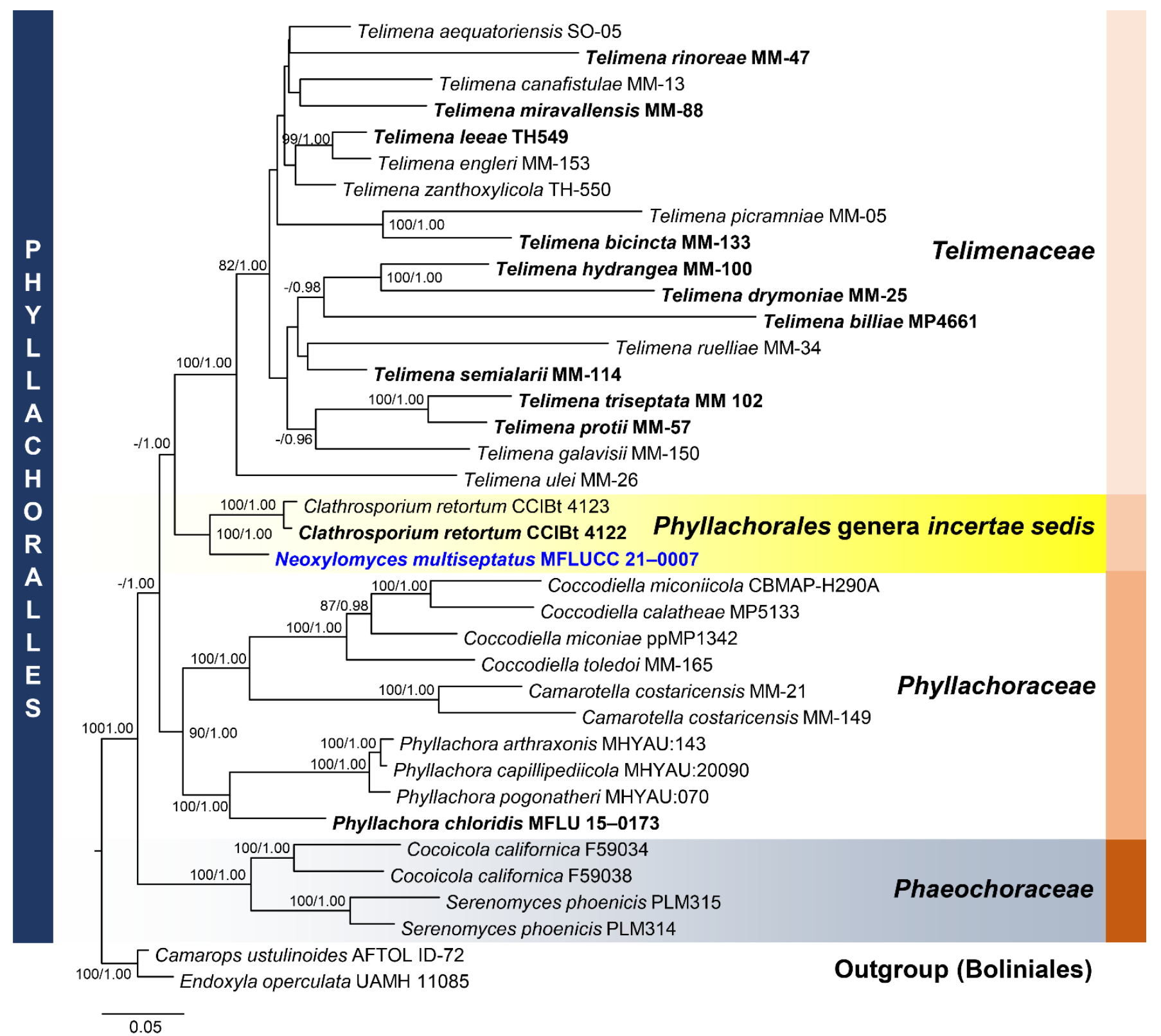

Figure 8. Phylogram generated from maximum likelihood analysis based on combined LSU, SSU, ITS, and TEF1- $\alpha$ sequence data representing the species of Phyllachorales and related taxa. Sequences are taken from Dayarathne et al. [72] and Yang et al. [73]. Thirty-seven taxa were included in the combined analyses, which comprised 3259 characters (LSU $=863$, SSU $=1175$, ITS $=462$, TEF1- $\alpha=759$ ) after alignment. The best scoring RAxML tree with a final likelihood value of $-32,589.920351$ is presented. The matrix had 2136 distinct alignment patterns, with $34.35 \%$ of undetermined characters or gaps. Estimated base frequencies were as follows: $\mathrm{A}=0.248688, \mathrm{C}=0.249512, \mathrm{G}=0.274933, \mathrm{~T}=0.226867$; substitution rates: $\mathrm{AC}=1.044099, \mathrm{AG}=1.599779, \mathrm{AT}=1.069911, \mathrm{CG}=1.048973, \mathrm{CT}=3.108380, \mathrm{GT}=1.000000$; gamma distribution shape parameter $\alpha=0.745075$. Bootstrap support values for ML equal to or greater than $75 \%$ and BYPP equal to or greater than 0.95 are given above the nodes. Camarops ustulinoides (AFTOL-ID 72) and Endoxyla operculata (UAMH 11085) were used as the outgroup taxa. The newly generated sequence is indicated in blue. The ex-type strains are indicated in bold. 

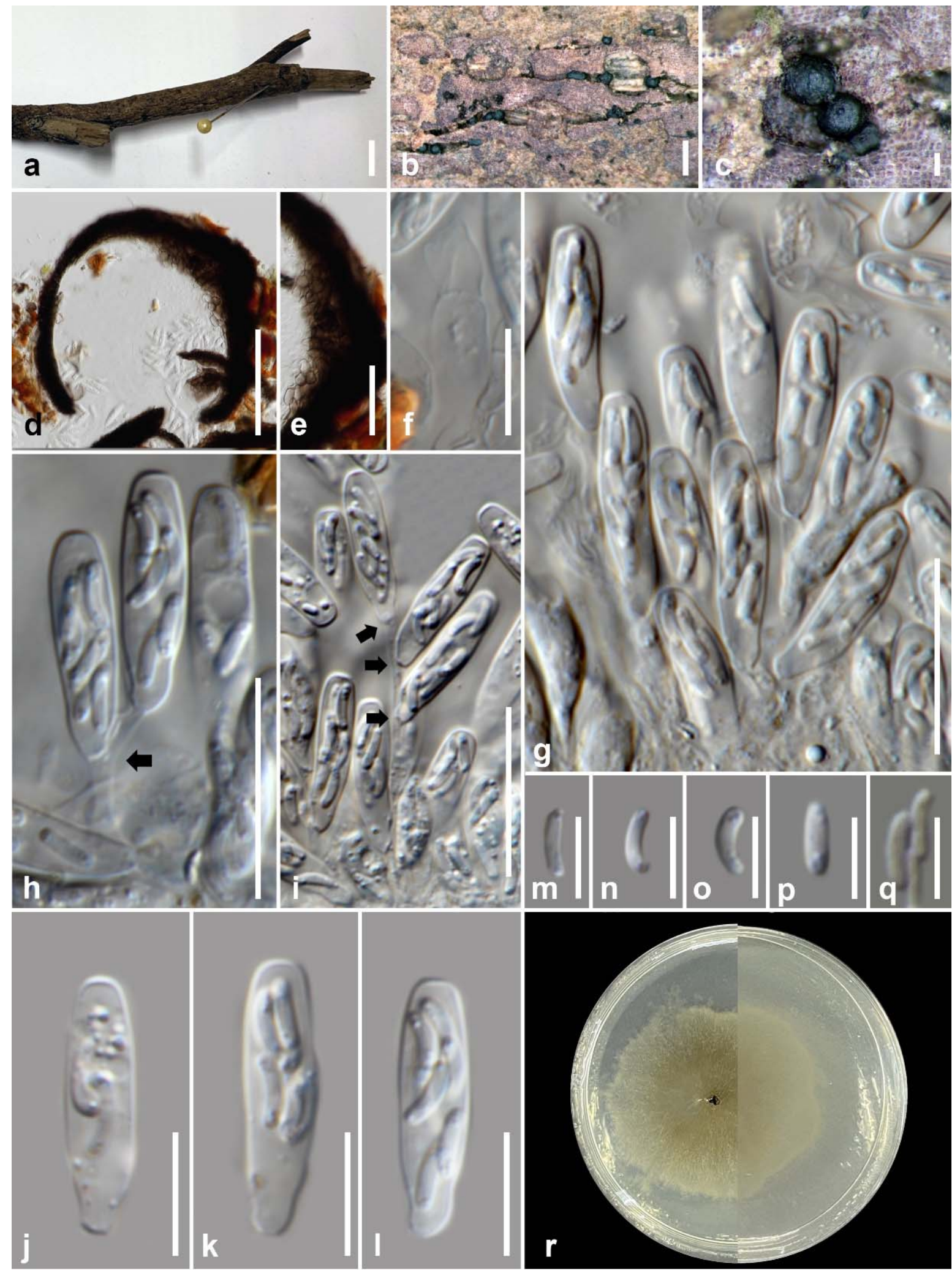

Figure 9. Phaeoacremonium thailandense (MFLU 21-0012, holotype). (a) Host; (b,c) ascomata on submerged wood; (d) section of an ascoma; (e) ascomatal wall; (f) paraphyses; (g-i) ascogenous hyphae (arrows); (j-l) asci; (m-p) ascospores; (q) germinated ascospores; (r) culture on MEA from surface and reverse. Scale bars: (a) $10 \mathrm{~mm}$; (b) $500 \mu \mathrm{m}$; (c-e) $100 \mu \mathrm{m}$; $(\mathbf{f}, \mathbf{j}-\mathbf{l}) 10 \mu \mathrm{m} ;(\mathbf{g}-\mathbf{i}) 20 \mu \mathrm{m} ;(\mathbf{m}-\mathbf{q}) 5 \mu \mathrm{m}$. 


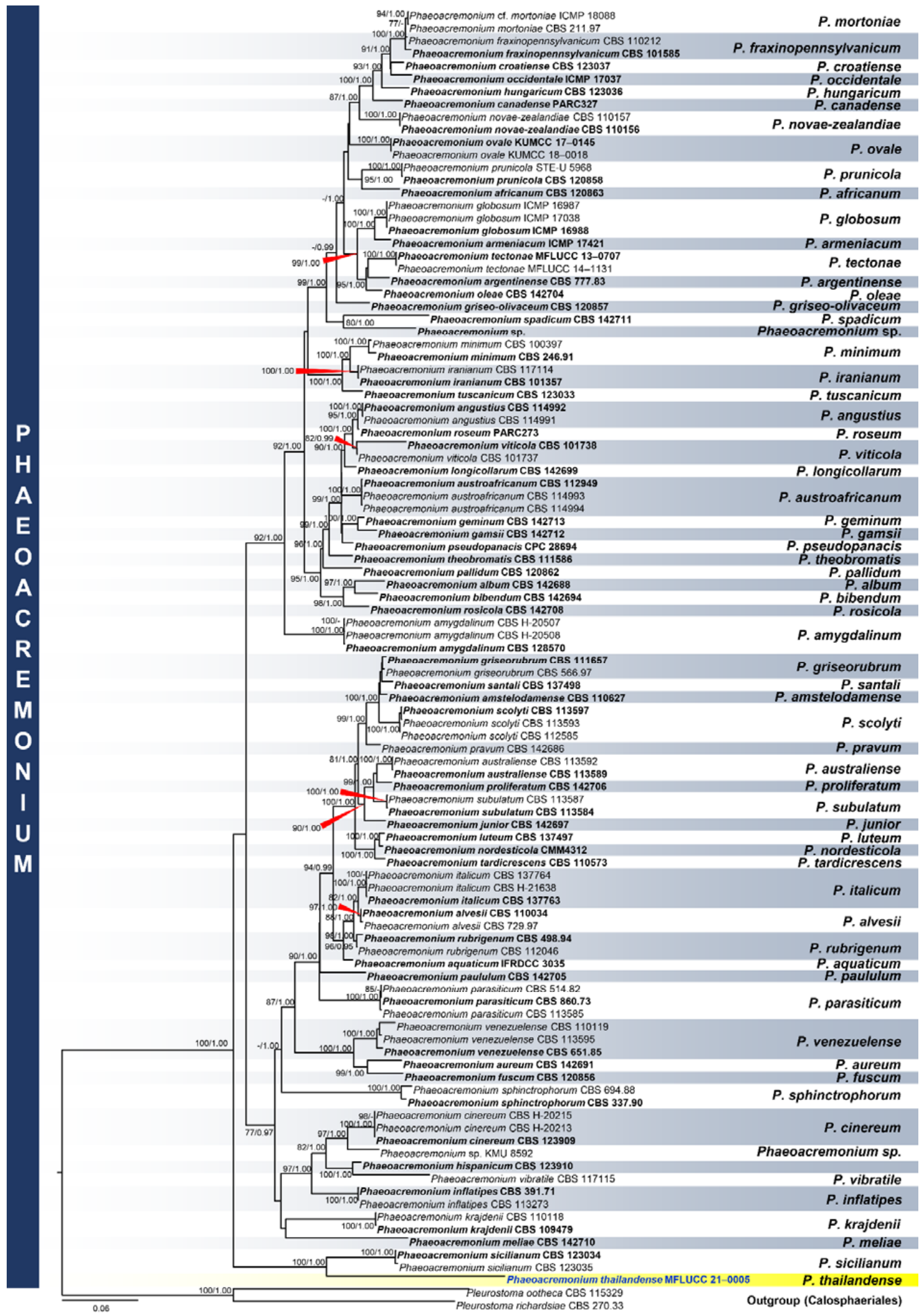

Figure 10. Phylogram generated from maximum likelihood analysis based on combined LSU, SSU, ITS, TEF1- $\alpha$, TUB2, and ACT sequence data representing the species of Phyllachorales and related taxa. Sequences are taken from Huang et al. [82]. One hundred-two taxa were included in the combined analyses, which comprised 2395 characters 
(LSU: 892, ITS: 527, TEF1- $\alpha=202$; TUB2: 513; ACT: 261) after alignment. The best scoring RAxML tree with a final likelihood value of -22707.720097 is presented. The matrix had 1011 distinct alignment patterns, with $45.51 \%$ of undetermined characters or gaps. Estimated base frequencies were as follows: $\mathrm{A}=0.228986, \mathrm{C}=0.288393, \mathrm{G}=0.253607, \mathrm{~T}=0.229013$; substitution rates: $\mathrm{AC}=1.333048, \mathrm{AG}=3.557820, \mathrm{AT}=1.416942, \mathrm{CG}=1.385484, \mathrm{CT}=4.971984, \mathrm{GT}=1.000000$; gamma distribution shape parameter $\alpha=0.255190$. Bootstrap support values for ML equal to or greater than $75 \%$ and BYPP equal to or greater than 0.95 are given above the nodes. Pleurostoma ootheca (CBS 115329) and Pleurostoma richardsiae (CBS 270.33) were used as the outgroup taxa. The newly generated sequence is indicated in blue. The ex-type strains are indicated in bold.

\section{Discussion}

Mycologists in Thailand have initiated a number of projects to document the diversity of freshwater fungi, and this article is a continuation of these studies. Freshwater fungi are an ecological group and include all the major phyla that occur on a wide range of substrates [2]. The first account of Thai freshwater fungi was by Tubaki et al. [83], who listed 40 Ingoldian fungi from foam samples from north and central Thailand. In 1996, BIOTEC initiated a project on lignicolous freshwater fungi under its Fungal Biodiversity Programme, resulting in Sivichai and Boonyene [84] listing 613 freshwater taxa for Thailand. The accumulative annual records of freshwater from 1996-2004 are presented in Figure S1. Zhang et al. [17] listed 173 (in 112 genera) freshwater species (including 34 Ingoldian fungi) published up to the end of 2010. Research on freshwater fungi in China started in the 1920s [85-87], and by 2013 [18] listed some 782 species, including 25 chytridiomycetes, 256 ascomycetes, 416 hyphomycetes, 63 oomycetes, and 22 zygomycetes.

We are constantly reminded that an estimated $39.4 \%$ of plants are now threatened with extinction, yet 1886 species of fungi were scientifically named for the first time in 2019 (Kew, Report State of the World's Plants and Fungi). In this article we have focused on the number of new taxa of freshwater fungi introduced over the past five years from samples collected in Thailand. This data shows that there seems no sign of it reaching a plateau [88].

Freshwater ascomycetes have been extensively studied over the past two decades $[8,10,14]$, but it was only in early 2000 that molecular data was used to resolve species [7,9,89-92]. Monographs and outlines of freshwater Dothideomycetes and Sordariomycetes have been provided by Dong et al. [14] and Luo et al. [10]. One hundred and forty-five genera of freshwater Dothideomycetes (six orders, 43 families) were included, with 32\% (46 genera) being unique to freshwater habitats [8,14]. Luo et al. [10] listed 451 species under 160 genera of freshwater Sordariomycetes.

In the present paper, five novel freshwater ascomycetes were introduced based on multi-loci phylogenetic analyses showing the high undiscovered diversity of fungi in lotic habitats in Thailand. Two new freshwater Dothideomycetes, Camposporium dulciaquae and Brunneofusispora hyalina, add to the increasing number of pleosporalean taxa discovered from freshwater habitats in Thailand. Based on the published works from 2015-2020, 40 novel pleosporolean taxa were discovered: Aigialaceae (1 species) [93], Anteagloniaceae (1 species) [14], Astrosphaeriellaceae (2 species) [14], Dictyosporiaceae (7 species) [14,94-97], Latoruaceae (2 species) [14,98], Lentitheciaceae (4 species) [20,99,100], Ligninsphaeriaceae (1 species) [15], Lindgomycetaceae (3 species) [14,101], Longipedicellataceae (3 species) [14], Lophiostomataceae (1 species) [14], Melanommataceae (1 species) [97], Morosphaeriaceae (3 species) [14,102], Nigrogranaceae (1 species) [14], Occultibambusaceae (1 species) [103], Parabambusicolaceae (1 species) [14], Phaeosphaeriaceae (1 species) [104], Pleosporales genera insertae sedis (2 species) [11,14], Pseudoastrosphaeriellaceae (1 species) [14], Tetraplosphaeriaceae (1 species) [14], Trematosphaeriaceae (1 species) [97], and Wicklowiaceae (2 species) $[19,24]$. Camposporium thailandicum is an addition to the known twelve Camposporium species recorded in freshwater habitats: C. antennatum [105-107], C. appendiculatum [27], C. cambrense [108-110], C. fusisporum [111], C. hyalinum [112], C. japonicum [108,110], C. marylandicum [113-115], C. multiseptatum [27], C. ontariense [108], C. pellucidum [27,107,108,110,114-116], C. quercicola [111], and C. septatum [27]. Brunneofusispora hyalina is the only known species of the genus thriving in freshwater habitats, while 
other species were collected on different plant hosts like Clematis subumbellata in Thailand (B. clematidis) [61] and Magnolia denudata, and an unknown host in China (B. sinensis) $[59,60]$.

Forty new species of freshwater Sordariomycetes were discovered in Thailand over the past five years, and taxa were members of Amphisphaeriales [10], Annulatascales [16], Chaetosphaeriales [10,97], Diaporthomycetidae genera incertae sedis $[59,117,118]$, Distoseptisporales [10,16,97,119,120], Magnaporthales [10], Microascales [10,121], Pleurotheciales [10,27,101,118], Pseudodactylariales [27], Savoryellales [27], Sporidesmiales [103], and Xylariales [10]. Three novel Sordariomycetes (Neoxylomyces multiseptatus, Phaeoacremonium thailandense, and Rattania aquatica) are additions to these species thriving in freshwater habitats in Thailand. Phaeoacremonium thailandense is the first reported freshwater species of Phaeoacremonium in Thailand. Other freshwater Phaeoacremonium species were recorded in China [81,82]. At present, five species, including the novel taxa, of Phaeoacremonium were recorded in Thailand and include P. aureum, isolated from mangrove plant Rhizophora mucronata, P. parasiticum causing human diseases [65,122], P. sphinctrophorum on dead bamboo culms [58], and P. tectonae on Tectona grandis [104]. Neoyxylomyces multiseptatus is the fourth species under Phyllachorales recorded in freshwater habitats. Other species recorded were Ascovaginospora stellipala, Phyllachora therophila, and Tamsiniella labiosa $[8,10]$. Rattania aquatica is the first member of the genus recorded from freshwater habitats and an addition to 59 species (12 genera) of freshwater Chaetosphaeriaceae.

Between the years 2015-2020, 129 novel species, dominated by Dothideomycetes with 86 species, followed by Sordariomycetes ( 40 species), have been discovered from freshwater habitats in Thailand (Figure S2, Table S1). Most of freshwater fungi were collected from streams, which reflects the ease of sampling in these sites. All these freshwater taxa were saprobes in submerged decaying woods. Most have an asexual morph form, wherein 80 and 4 species were hyphomycetes and coelomycetes, respectively. Thirty-five species were sexual morphs, and 10 species had both sexual-asexual morphs. The discovery of five novel freshwater ascomycetes (1 sexual morph, 4 asexual morphs) add to the increasing number of fungi discovered in Thailand for the past six years (Figure S3). Future work needs to explore various lentic and lotic habitats and different substrates in freshwater environments of Thailand. While the Ascomycota dominate taxa recovered from freshwater habitats, much remains to be done to survey other major taxa and develop better techniques for their enumeration, such as members of the Basidiomycota (only 115 are listed by Jones et al. [2]), Zygomycota, Mucoromycota, and microsporidians [2]. These groups must be covered so as to determine the overall diversity of freshwater fungi in Thailand.

Supplementary Materials: The following are available online at https:/ / www.mdpi.com/2309-6 08X/7/2/117/s1, Table S1: Freshwater fungi discovered from 2015-2020 in Thailand, Figure S1: Annual cumulative number of freshwater fungi recorded for Thailand from 1996-2004. (Adapted from Sivichai and Boonyene), Figure S2: Classification of novel freshwater fungi discovered from Thailand from 2015-2020, Figure S3: Total number of novel freshwater fungi discovered from Thailand from 2015-2020.

Author Contributions: Conceptualization: M.S.C., K.D.H.; methodology: M.S.C., K.D.H.; formal analysis and investigation: M.S.C., K.D.H., E.B.G.J.; resources: K.D.H., E.B.G.J., M.D.; writingoriginal draft preparation, M.S.C.; writing—review and editing, K.D.H., E.B.G.J., S.B., M.D., S.L.; supervision, K.D.H.; funding acquisition, K.D.H., E.B.G.J., S.B., M.D. All authors have read and agreed to the published version of the manuscript.

Funding: K.D.H. thanks the Thailand Research Fund for the grant entitled "Impact of climate change on fungal diversity and biogeography in the Greater Mekong Subregion" (Grant No. RDG6130001). M.S.C. is grateful to the CAS President's International Fellowship Initiative (PIFI) for Young Staff 2019-2021 (grant number 2019FY0003), The Yunnan Provincial Department of Human Resources and Social Security (Grant No. Y836181261), and The National Science Foundation of China (NSFC) project code 31850410489. E.B.G.J. is supported under the Distinguished Scientist Fellowship Program (DSFP), King Saud University, Kingdom of Saudi Arabia. M.D. is supported by the 5th batch of Postdoctoral Orientation Training Personnel in Yunnan Province (grant no.: Y934283261), the 64th batch of China Postdoctoral Science Foundation (grant no.: Y913082271), and Chiang Mai University. 
Institutional Review Board Statement: Not applicable.

Informed Consent Statement: Not applicable.

Data Availability Statement: All sequences generated in this study were submitted to GenBank.

Acknowledgments: M.S.C. is grateful to Mushroom Research Foundation and Department of Science and Technology—Science Education Institute (Philippines). K.D.H. thanks Chiang Mai University for the award of Visiting Professor. The authors are grateful to Sajeewa Maharachchikumbura, Ausana Mapook, Rungtiwa Phookamsak, Chun-Fang Liao, and Er-Fu Yang for helping with the molecular analysis of the samples. All authors thank Shaun Pennycook for his advice in the fungal names.

Conflicts of Interest: The authors declare no conflict of interests.

\section{References}

1. Tsui, C.K.M.; Hyde, K.D. Freshwater Mycology; Fungal Diversity Press: Hongkong, China, 2003.

2. Jones, E.B.G.; Yanna; Hyde, K.D.; Pang, K.L. Freshwater Fungi and Fungal-Like Organisms; De Gruyter: Berlin, Germany, 2014.

3. Ho, W.H.; Hyde, K.D.; Hodgkiss, I.J. Seasonality and sequential occurrence of fungi on wood submerged in Tai Po Kau Forest Stream, Hong Kong. Fungal Divers. 2002, 10, 21-43.

4. Hyde, K.D.; Goh, T.K. Fungi on submerged wood in Lake Barrine, north Queensland, Australia. Mycol. Res. 1998, 102, 739-749. [CrossRef]

5. Jones, E.B.G. Are there more marine fungi to be described? Bot. Mar. 2011, 54, 343-354. [CrossRef]

6. Jones, E.B.G.; Pang, K.L.; Abdel-Wahab, M.A.; Scholz, B.; Hyde, K.D.; Boekhout, T.; Ebel, R.; Rateb, M.E.; Henderson, L.; Sakayaroj, J.; et al. An online resource for marine fungi. Fungal Divers. 2019, 96, 347-433. [CrossRef]

7. Shearer, C.A.; Raja, H.A.; Miller, A.N.; Nelson, P.; Tanaka, K.; Hirayama, K.; Marvanová, L.; Hyde, K.D.; Zhang, Y. The molecular phylogeny of freshwater Dothideomycetes. Stud. Mycol. 2009, 64, 145-153. [CrossRef] [PubMed]

8. Calabon, M.; Hyde, K.; Jones, E.; Chandrasiri, S.; Dong, W.; Fryar, S.; Yang, J.; Luo, Z.; Lu, Y.; Bao, D.; et al. www.freshwaterfungi.org, an online platform for the taxonomic classification of freshwater fungi. Asian J. Mycol. 2020, 3, 419-445. [CrossRef]

9. Yang, J.; Liu, N.G.; Liu, J.K.; Hyde, K.D.; Jones, E.B.G.; Liu, Z.Y. Phylogenetic placement of Cryptophiale, Cryptophialoidea, Nawawia, Neonawawia gen. nov. and Phialosporostilbe. Mycosphere 2018, 9, 1132-1150. [CrossRef]

10. Luo, Z.L.; Hyde, K.D.; Liu, J.K.; Maharachchikumbura, S.S.N.; Jeewon, R.; Bao, D.F.; Bhat, D.J.; Lin, C.G.; Li, W.L.; Yang, J.; et al. Freshwater Sordariomycetes. Fungal Divers. 2019, 99, 451-660. [CrossRef]

11. Calabon, M.S.; Hyde, K.D.; Jones, E.B.G.; Doilom, M.; Liao, C.F.; Boonmee, S. Mycoenterolobium aquadictyosporium sp. nov. (Pleosporomycetidae, Dothideomycetes) from a freshwater habitat in Thailand. Mycol. Prog. 2020, 19, 1031-1042. [CrossRef]

12. Samarakoon, B.C.; Wanasinghe, D.N.; Samarakoon, M.C.; Phookamsak, R.; McKenzie, E.H.C.; Chomnunti, P.; Hyde, K.D.; Lumyong, S.; Karunarathna, S.C. Multi-gene phylogenetic evidence suggests Dictyoarthrinium belongs in Didymosphaeriaceae (Pleosporales, Dothideomycetes) and Dictyoarthrinium musae sp. nov. on Musa from Thailand. MycoKeys 2020, 71, 101-118. [CrossRef]

13. Samarakoon, M.C.; Maharachchikumbura, S.S.N.; Liu, J.K.; Hyde, K.D.; Promputtha, I.; Stadler, M. Molecular phylogeny and morphology of Amphisphaeria (= Lepteutypa) (Amphisphaeriaceae). J. Fungi 2020, 6, 174. [CrossRef] [PubMed]

14. Dong, W.; Wang, B.; Hyde, K.D.; McKenzie, E.H.C.; Raja, H.A.; Tanaka, K.; Abdel-Wahab, M.A.; Abdel-Aziz, F.A.; Doilom, M.; Phookamsak, R.; et al. Freshwater Dothideomycetes. Fungal Divers. 2020, 105, 319-575. [CrossRef]

15. Hongsanan, S.; Hyde, K.D.; Phookamsak, R.; Wanasinghe, D.N.; McKenzie, E.H.C.; Sarma, V.V.; Boonmee, S.; Lücking, R.; Bhat, D.J.; Liu, N.G.; et al. Refined families of Dothideomycetes: Dothideomycetidae and Pleosporomycetidae. Mycosphere 2020, 11, 1553-2107. [CrossRef]

16. Hyde, K.D.; Norphanphoun, C.; Maharachchikumbura, S.S.N.; Bhat, D.J.; Jones, E.B.G.; Bundhun, D.; Chen, Y.-J.; Bao, D.-F.; Boonmee, S.; Calabon, M.S.; et al. Refined families of Sordariomycetes. Mycosphere 2020, 11, 305-1059. [CrossRef]

17. Zhang, H.; Jones, G.E.B.; Zhou, D.; Bahkali, A.H.; Hyde, K.D. Checklist of freshwater fungi in Thailand. Cryptogam. Mycol. 2011, 32, 199-217. [CrossRef]

18. Hu, D.M.; Liu, F.; Cai, L. Biodiversity of aquatic fungi in China. Mycology 2013, 4, 125-168. [CrossRef]

19. Calabon, M.S.; Hyde, K.D.; Gentekaki, E.; Jones, E.B.G.; Phookamsak, R.; Doilom, M.; Boonmee, S.; Promputtha, I. Wicklowia phuketensis (Wicklowiaceae, Pleosporales), a novel freshwater taxon from Thailand. Phytotaxa 2020, 452, 55-64. [CrossRef]

20. Calabon, M.S.; Jones, E.B.G.; Hyde, K.D.; Boonmee, S.; Tibell, S.; Tibell, L.; Pang, K.L.; Phookamsak, R. Phylogenetic assessment and taxonomic revision of Halobyssothecium and Lentithecium (Lentitheciaceae, Pleosporales). Mycol. Prog. 2021. [CrossRef]

21. Luo, Z.L.; Bhat, D.J.; Jeewon, R.; Boonmee, S.; Bao, D.F.; Zhao, Y.C.; Chai, H.M.; Su, H.Y.; Su, X.J.; Hyde, K.D. Molecular phylogeny and morphological characterization of asexual fungi (Tubeufiaceae) from freshwater habitats in Yunnan, China. Cryptogam. Mycol. 2017, 38, 27-53. [CrossRef]

22. Lu, Y.Z.; Liu, J.K.; Hyde, K.D.; Jeewon, R.; Kang, J.C.; Fan, C.; Boonmee, S.; Bhat, D.J.; Luo, Z.L.; Lin, C.G.; et al. A taxonomic reassessment of Tubeufiales based on multi-locus phylogeny and morphology. Fungal Divers. 2018, 92, 131-344. [CrossRef] 
23. Bao, D.F.; Su, H.Y.; Maharachchikumbura, S.S.N.; Liu, J.K.; Nalumpang, S.; Luo, Z.L.; Hyde, K.D. Lignicolous freshwater fungi from China and Thailand: Multi-gene phylogeny reveals new species and new records in Lophiostomataceae. Mycosphere 2019, 10, 1080-1099. [CrossRef]

24. Boonmee, S.; Sorvongxay, T.; Huanraluek, N.; Hyde, K.D. Wicklowia submersa sp. nov. (Wicklowiaceae, Pleosporales), a second species in a monotypic family. Phytotaxa 2019, 411, 73-83. [CrossRef]

25. Bao, D.F.; McKenzie, E.H.C.; Bhat, D.J.; Hyde, K.D.; Luo, Z.L.; Shen, H.W.; Su, H.Y. Acrogenospora (Acrogenosporaceae, Minutisphaerales) appears to be a very diverse genus. Front. Microbiol. 2020, 1606. [CrossRef]

26. Dong, W.; Hyde, K.D.; Doilom, M.; Yu, X.D.; Bhat, D.J.; Jeewon, R.; Boonmee, S.; Wang, G.N.; Nalumpang, S.; Zhang, H. Pseudobactrodesmium (Dactylosporaceae, Eurotiomycetes, Fungi) a novel lignicolous genus. Front. Microbiol. 2020, 11, 456. [CrossRef]

27. Hyde, K.D.; Dong, Y.; Phookamsak, R.; Jeewon, R.; Bhat, D.J.; Jones, E.B.G.; Liu, N.G.; Abeywickrama, P.D.; Mapook, A.; Wei, D.; et al. Fungal diversity notes 1151-1276: Taxonomic and phylogenetic contributions on genera and species of fungal taxa. Fungal Divers. 2020, 100, 5-277. [CrossRef]

28. Hyde, K.D.; Fryar, S.; Tian, Q.; Bahkali, A.H.; Xu, J. Lignicolous freshwater fungi along a north-south latitudinal gradient in the Asian/Australian region; can we predict the impact of global warming on biodiversity and function? Fungal Ecol. 2016, 19, 190-200. [CrossRef]

29. Senanayake, I.C.; Rathnayaka, A.R.; Marasinghe, D.S.; Calabon, M.S.; Gentekaki, E.; Lee, H.B.; Hurdeal, V.G.; Pem, D.; Dissanayake, L.S.; Wijesinghe, S.N.; et al. Morphological approaches in studying fungi: Collection, examination, isolation, sporulation and preservation. Mycosphere 2020, 11, 2678-2754. [CrossRef]

30. Jayasiri, S.C.; Hyde, K.D.; Ariyawansa, H.A.; Bhat, J.; Buyck, B.; Cai, L.; Dai, Y.C.; Abd-Elsalam, K.A.; Ertz, D.; Hidayat, I.; et al. The Faces of Fungi database: Fungal names linked with morphology, phylogeny and human impacts. Fungal Divers. 2015, 74, 3-18. [CrossRef]

31. Crous, P.W.; Gams, W.; Stalpers, J.A.; Robert, V.; Stegehuis, G. MycoBank: An online initiative to launch mycology into the 21st century. Stud. Mycol. 2004, 50, 19-22.

32. Dissanayake, A.J.; Bhunjun, C.S.; Maharachchikumbura, S.S.N.; Liu, J.K. Applied aspects of methods to infer phylogenetic relationships amongst fungi. Mycosphere 2020, 11, 2652-2676. [CrossRef]

33. Vilgalys, R.; Hester, M. Rapid genetic identification and mapping of enzymatically amplified ribosomal DNA from several Cryptococcus species. J. Bacteriol. 1990, 172, 4238-4246. [CrossRef]

34. White, T.; Bruns, T.; Lee, S.; Taylor, J. Amplification and direct sequencing of fungal ribosomal RNA genes for phylogenetics. In PCR Protocols, a Guide to Methods and Applications; Innis, M.A., Gelfand, D.H., Sninsky, J.J., White, T.J., Eds.; Academic Press: San Diego, CA, USA, 1990; pp. 315-322.

35. Rehner, S.A.; Buckley, E. A Beauveria phylogeny inferred from nuclear ITS and EF1- $\alpha$ sequences: Evidence for cryptic diversification and links to Cordyceps teleomorphs. Mycologia 2005, 97, 84-98. [CrossRef]

36. O'Donnell, K.; Cigelnik, E. Two divergent intragenomic rDNA ITS2 types within a monophyletic lineage of the fungus Fusarium are nonorthologous. Mol. Phylogenet. Evol. 1997, 7, 103-116. [CrossRef]

37. Glass, N.L.; Donaldson, G.C. Development of primer sets designed for use with the PCR to amplify conserved genes from filamentous ascomycetes. Appl. Environ. Microbiol. 1995, 61, 1323-1330. [CrossRef] [PubMed]

38. Carbone, I.; Kohn, L.M. A method for designing primer sets for speciation studies in filamentous ascomycetes. Mycologia 1999, 91, 553-556. [CrossRef]

39. Katoh, K.; Rozewicki, J.; Yamada, K.D. MAFFT online service: Multiple sequence alignment, interactive sequence choice and visualization. Brief. Bioinform. 2019, 20, 1160-1166. [CrossRef] [PubMed]

40. Hall, T.A. BioEdit: A user-friendly biological sequence alignment editor and analysis program for Windows 95/98/NT. Nucleic Acids Symp. Ser. 1999, 41, 95-98.

41. Glez-Peña, D.; Gómez-Blanco, D.; Reboiro-Jato, M.; Fdez-Riverola, F.; Posada, D. ALTER: Program-oriented conversion of DNA and protein alignments. Nucleic Acids Res. 2010, 38, W14-W18. [CrossRef] [PubMed]

42. Stamatakis, A. RAxML-VI-HPC: Maximum likelihood-based phylogenetic analyses with thousands of taxa and mixed models. Bioinformatics 2006, 22, 2688-2690. [CrossRef] [PubMed]

43. Stamatakis, A.; Hoover, P.; Rougemont, J. A rapid bootstrap algorithm for the RAxML web servers. Syst. Biol. 2008, 57, 758-771. [CrossRef]

44. Stamatakis, A. RAxML version 8: A tool for phylogenetic analysis and post-analysis of large phylogenies. Bioinformatics 2014, 30, 1312-1313. [CrossRef]

45. Miller, M.A.; Pfeiffer, W.; Schwartz, T. Creating the CIPRES Science Gateway for inference of large phylogenetic trees. In Proceedings of the Gateway Computing Environments Workshop, New Orleans, LA, USA, 14 November 2010; pp. 1-8.

46. Nylander, J.A.A. MrModeltest 2.0. In Program Distributed by the Author; Uppsala University: Uppsala, Sweden, 2004.

47. Ronquist, F.; Huelsenbeck, J.P. MrBayes 3: Bayesian phylogenetic inference under mixed models. Bioinformatics 2003, 19, 1572-1574. [CrossRef]

48. Hyde, K.D.; Jones, E.B.G.; Liu, J.K.; Ariyawansa, H.; Boehm, E.; Boonmee, S.; Braun, U.; Chomnunti, P.; Crous, P.W.; Dai, D.Q.; et al. Families of Dothideomycetes. Fungal Divers. 2013, 63, 1-313. [CrossRef] 
49. Wijayawardene, N.N.; Hyde, K.D.; Al-ani, L.K.T.; Tedersoo, L.; Haelewaters, D.; Rajeshkumar, K.C.; Zhao, R.; Aptroot, A.; Leontyev, D.V.; Ramesh, K.; et al. Outline of Fungi and fungus-like taxa. Mycosphere 2020, 11, 1-367. [CrossRef]

50. Winter, G.P. Ascomyceten. In Rabenhorst's Kryptogamen-Flora von Deutschland, Oesterreich und der Schweiz; Eduard Kummer: Leipzig, Germany, 1885; Volume 1, pp. 1-928.

51. Harkness, H.W. New species of California fungi. Bull. South. Calif. Acad. Sci. 1884, 1, $29-47$.

52. Hughes, S.J. Studies on micro-fungi. III. Mastigosporium, Camposporium, and Ceratophoram. Mycol. Pap. 1951, 36, 1-43.

53. Ellis, M.B. Dematiaceous Hyphomycetes; Commonwealth Mycological Institute: Kew, UK, 1971.

54. Ichinoe, M. Camposporium species from Japan. Trans. Mycol. Soc. Jpn. 1971, 12, 79-88.

55. Whitton, S.R.; McKenzie, E.H.C.; Hyde, K.D. Microfungi on the Pandanaceae: Two new species of Camposporium and key to the genus. Fungal Divers. 2002, 11, 177-187.

56. Hernández-Restrepo, M.; Gené, J.; Castañeda-Ruiz, R.F.; Mena-Portales, J.; Crous, P.W.; Guarro, J. Phylogeny of saprobic microfungi from Southern Europe. Stud. Mycol. 2017, 86, 53-97. [CrossRef]

57. Hyde, K.D.; Chethana, K.W.T.; Jayawardena, R.S.; Luangharn, T.; Calabon, M.S.; Jones, E.B.G.; Hongsanan, S.; Lumyong, S. The rise of mycology in Asia. ScienceAsia 2020, 46S, 1-11. [CrossRef]

58. Dai, D.Q.; Phookamsak, R.; Wijayawardene, N.N.; Li, W.J.; Bhat, D.J.; Xu, J.C.; Taylor, J.E.; Hyde, K.D.; Chukeatirote, E. Bambusicolous fungi. Fungal Divers. 2017, 82, 1-105. [CrossRef]

59. Phookamsak, R.; Hyde, K.D.; Jeewon, R.; Bhat, D.J.; Jones, E.B.G.; Maharachchikumbura, S.S.N.; Raspé, O.; Karunarathna, S.C.; Wanasinghe, D.N.; Hongsanan, S.; et al. Fungal diversity notes 929-1035: Taxonomic and phylogenetic contributions on genera and species of fungi. Fungal Divers. 2019, 95, 1-273. [CrossRef]

60. Wanasinghe, D.N.; Wijayawardene, N.N.; Xu, J.; Cheewangkoon, R.; Mortimer, P.E. Taxonomic novelties in Magnolia-associated pleosporalean fungi in the Kunming Botanical Gardens (Yunnan, China). PLoS ONE 2020, 15, e0235855. [CrossRef]

61. Phukhamsakda, C.; McKenzie, E.H.C.; Phillips, A.J.L.; Gareth Jones, E.B.; Jayarama Bhat, D.; Stadler, M.; Bhunjun, C.S.; Wanasinghe, D.N.; Thongbai, B.; Camporesi, E.; et al. Microfungi associated with Clematis (Ranunculaceae) with an integrated approach to delimiting species boundaries. Fungal Divers. 2020, 102, 1-203. [CrossRef]

62. Tibpromma, S.; Hyde, K.D.; McKenzie, E.H.C.; Bhat, D.J.; Phillips, A.J.L.; Wanasinghe, D.N.; Samarakoon, M.C.; Jayawardena, R.S.; Dissanayake, A.J.; Tennakoon, D.S.; et al. Fungal diversity notes 840-928: Micro-fungi associated with Pandanaceae. Fungal Divers. 2018, 93, 1-160. [CrossRef]

63. Huhndorf, S.M.; Miller, A.N.; Fernández, F.A. Molecular systematics of the Sordariales: The order and the family Lasiosphaeriaceae redefined. Mycologia 2004, 96, 368-387. [CrossRef]

64. Lin, C. Hyaline-spored chaetosphaeriaceous hyphomycetes from Thailand and China, with a review of the family Chaetosphaeriaceae. Mycosphere 2019, 10, 655-700. [CrossRef]

65. Prabhugaonkar, A.; Bhat, D.J. Rattania setulifera, an undescribed endophytic hyphomycete on rattans from western ghats, India. Mycotaxon 2009, 108, 217-222. [CrossRef]

66. Shenoy, B.D.; Jeewon, R.; Wang, H.; Amandeep, K.; Ho, W.H.; Bhat, D.J.; Crous, P.W.; Hyde, K.D. Sequence data reveals phylogenetic affinities of fungal anamorphs Bahusutrabeeja, Diplococcium, Natarajania, Paliphora, Polyschema, Rattania and Spadicoides. Fungal Divers. 2010, 44, 161-169. [CrossRef]

67. Barr, M.E. The ascomycete connection. Mycologia 1983, 75, 1-13. [CrossRef]

68. Mardones, M.; Trampe-Jaschik, T.; Oster, S.; Elliott, M.; Urbina, H.; Schmitt, I.; Piepenbring, M. Phylogeny of the order Phyllachorales (Ascomycota, Sordariomycetes): Among and within order relationships based on five molecular loci. Pers. Mol. Phylogeny Evol. Fungi 2017, 39, 74-90. [CrossRef]

69. Goh, T.K.; Ho, W.H.; Hyde, K.D.; Tsui, K.M. Four new species of Xylomyces from submerged wood. Mycol. Res. 1997, 101, 1323-1328. [CrossRef]

70. Jiang, M.; Wongsawas, M.; Wang, H.; Lin, F.; Liang, Y. Three new records of lignicolous freshwater hyphomycetes from Mainland China. J. Agric. Technol. Y.C. China J. Agric. Technol. 2008, 4, 101-108.

71. Moro, L.B.; Delgado, G.; Schoenlein-Crusius, I.H. Clathrosporium retortum, a novel aeroaquatic fungus in the Sordariomycetidae (Ascomycota) from Brazil. Phytotaxa 2015, 239, 17-29. [CrossRef]

72. Dayarathne, M.C.; Maharachchikumbura, S.S.N.; Jones, E.B.G.; Goonasekara, I.D.; Bulgakov, T.S.; Al-Sadi, A.M.; Hyde, K.D.; Lumyong, S.; McKenzie, E.H.C. Neophyllachora gen nov. (Phyllachorales), three new species of Phyllachora from Poaceae and resurrection of Polystigmataceae (Xylariales). Mycosphere 2017, 8, 1598-1625. [CrossRef]

73. Yang, C.L.; Xu, X.L.; Liu, Y.G.; Hyde, K.D.; McKenzie, E.H.C. A new species of Phyllachora (Phyllachoraceae, Phyllachorales) on Phyllostachys heteroclada from Sichuan, China. Phytotaxa 2019, 392, 186-196. [CrossRef]

74. Maharachchikumbura, S.S.N.; Hyde, K.D.; Jones, E.B.G.; McKenzie, E.H.C.; Huang, S.K.; Abdel-Wahab, M.A.; Daranagama, D.A.; Dayarathne, M.; D'souza, M.J.; Goonasekara, I.D.; et al. Towards a natural classification and backbone tree for Sordariomycetes. Fungal Divers. 2015, 72, 199-301. [CrossRef]

75. Réblová, M.; Jaklitsch, W.M.; Réblová, K.; Štěpánek, V. Phylogenetic reconstruction of the Calosphaeriales and Togniniales using five genes and predicted RNA secondary structures of ITS, and Flabellascus tenuirostris gen. et sp. nov. PLoS ONE 2015, 10, e0144616. [CrossRef] [PubMed]

76. Réblová, M.; Mostert, L.; Gams, W.; Crous, P.W. New genera in the Calosphaeriales: Togniniella and its anamorph Phaeocrella, and Calosphaeriophora as anamorph of Calosphaeria. Stud. Mycol. 2004, 50, 533-550. 
77. Mostert, L.; Crous, P.W.; Groenewald, J.Z.; Gams, W.; Summerbell, R.C. Togninia (Calosphaeriales) is confirmed as teleomorph of Phaeoacremonium by means of morphology, sexual compatibility and DNA phylogeny. Mycologia 2003, 95, 646-659. [CrossRef]

78. Mostert, L.; Groenewald, J.Z.; Summerbell, R.C.; Gams, W.; Crous, P.W. Taxonomy and pathology of Togninia (Diaporthales) and its Phaeoacremonium anamorphs. Stud. Mycol. 2006, 54, 1-115. [CrossRef]

79. Crous, P.W.; Gams, W.; Wingfield, M.J.; Van Wyk, P.S. Phaeoacremonium gen. nov. associated with with and decline diseases of woody hosts and human infections. Mycologia 1996, 88, 786-796. [CrossRef]

80. Gramaje, D.; Mostert, L.; Groenewald, J.Z.; Crous, P.W. Phaeoacremonium: From esca disease to phaeohyphomycosis. Fungal Biol. 2015, 119, 759-783. [CrossRef]

81. Hu, D.M.; Cai, L.; Hyde, K.D. Three new ascomycetes from freshwater in China. Mycologia 2012, 104, 1478-1489. [CrossRef]

82. Huang, S.K.; Jeewon, R.; Hyde, K.D.; Jayarama Bhat, D.; Chomnunti, P.; Wen, T.C. Beta-tubulin and Actin gene phylogeny supports Phaeoacremonium ovale as a new species from freshwater habitats in China. MycoKeys 2018, 41, 1-15. [CrossRef]

83. Tubaki, K.; Watanabe, K.; Manoch, L. Aquatic hyphomycetes from Thailand. Trans. Mycol. Soc. Jpn. 1983, 24, 451-457.

84. Sivichai, S.; Boonyene, N. Freshwater fungi. In Thai Fungal Diversity; Jones, E.B.G., Tanticharoen, M., Hyde, K.D., Eds.; BIOTEC: Pathum Thani, Thailand, 2004; pp. 95-106.

85. Thaxter, R. Contribution toward a Monograph of the Laboulbeniaceæ: Part II. Mem. Am. Acad. Arts Sci. 1908, 14, 315-426. [CrossRef]

86. Thaxter, R. Contribution towards a Monograph of the Laboulbeniaceæ. Part IV. Mem. Am. Acad. Arts Sci. 1926, 15, 431-555. [CrossRef]

87. Skvortzow, B. Zur Kenntnis der Phycomyceten aus der Nordmandshurei, China. Archiv für Protistenkunde 1925, 51, 428-433.

88. Sivichai, S. Tropical freshwater fungi: Their ecology and taxonomy. Ph.D. Thesis, University of Portsmouth, Portsmouth, UK, 2000.

89. Shearer, C.A.; Pang, K.-L.; Suetrong, S.; Raja, H.A. Phylogeny of the Dothideomycetes and other classes of freshwater fissitunicate Ascomycota. In Freshwater Fungi; Jones, E., Hyde, K., Pang, K., Eds.; Walter de Gruyter: Berlin, Germany, $2014 ;$ pp. 25-46.

90. Cai, L.; Hu, D.-M.; Liu, F.; Hyde, K.D.; Jones, E.B.G. The molecular phylogeny of freshwater Sordariomycetes and Discomycetes. In Freshwater Fungi; Jones, E., Hyde, K., Pang, K., Eds.; Walter de Gruyter: Berlin, Germany, 2014; pp. 47-72.

91. Boonmee, S.; Rossman, A.Y.; Liu, J.K.; Li, W.J.; Dai, D.Q.; Bhat, J.D.; Jones, E.B.G.; McKenzie, E.H.C.; Xu, J.C.; Hyde, K.D. Tubeufiales, ord. nov., integrating sexual and asexual generic names. Fungal Divers. 2014, 68, 239-298. [CrossRef]

92. Hyde, K. Incorporating molecular data in fungal systematics: A guide for aspiring researchers. Curr. Res. Environ. Appl. Mycol. 2013, 3, 1-32. [CrossRef]

93. Bao, D.F.; Luo, Z.L.; Jeewon, R.; Nalumpang, S.; Su, H.Y.; Hyde, K.D. Neoastrosphaeriella aquatica sp. nov. (Aigialaceae), a new species from freshwater habitat in Southern Thailand. Phytotaxa 2019, 391, 197-206. [CrossRef]

94. Yang, J.; Liu, J.K.; Hyde, K.D.; Gareth Jones, E.B.; Liu, Z.Y. New species in Dictyosporium, new combinations in Dictyocheirospora and an updated backbone tree for Dictyosporiaceae. MycoKeys 2018, 36, 83-105. [CrossRef]

95. Boonmee, S.; D’souza, M.J.; Luo, Z.; Pinruan, U.; Tanaka, K.; Su, H.; Bhat, D.J.; McKenzie, E.H.C.; Jones, E.B.G.; Taylor, J.E.; et al. Dictyosporiaceae fam. nov. Fungal Divers. 2016, 80, 457-482. [CrossRef]

96. Liu, J.K.; Hyde, K.D.; Jones, E.B.G.; Ariyawansa, H.A.; Bhat, D.J.; Boonmee, S.; Maharachchikumbura, S.S.N.; McKenzie, E.H.C.; Phookamsak, R.; Phukhamsakda, C.; et al. Fungal diversity notes 1-110: Taxonomic and phylogenetic contributions to fungal species. Fungal Divers. 2015, 72, 1-197. [CrossRef]

97. Hyde, K.D.; Tennakoon, D.S.; Jeewon, R.; Bhat, D.J.; Maharachchikumbura, S.S.N.; Rossi, W.; Leonardi, M.; Lee, H.B.; Mun, H.Y.; Houbraken, J.; et al. Fungal diversity notes 1036-1150: Taxonomic and phylogenetic contributions on genera and species of fungal taxa. Fungal Divers. 2019, 96, 1-242. [CrossRef]

98. Tibpromma, S.; Hyde, K.D.; Jeewon, R.; Maharachchikumbura, S.S.N.; Liu, J.K.; Bhat, D.J.; Jones, E.B.G.; McKenzie, E.H.C.; Camporesi, E.; Bulgakov, T.S.; et al. Fungal diversity notes 491-602: Taxonomic and phylogenetic contributions to fungal taxa. Fungal Divers. 2017, 83, 1-261. [CrossRef]

99. Luo, Z.L.; Bahkali, A.H.; Liu, X.Y.; Phookamsak, R.; Zhao, Y.C.; Zhou, D.Q.; Su, H.Y.; Hyde, K.D. Poaceascoma aquaticum sp. nov. (Lentitheciaceae), a new species from submerged bamboo in freshwater. Phytotaxa 2016, 253, 71-80. [CrossRef]

100. Xu, L.; Bao, D.F.; Luo, Z.L.; Su, X.J.; Shen, H.W.; Su, H.Y. Lignicolous freshwater ascomycota from Thailand: Phylogenetic and morphological characterisation of two new freshwater fungi: Tingoldiago hydei sp. nov. and T. clavata sp. nov. and eastern Thailand. MycoKeys 2020, 65, 119-138. [CrossRef]

101. Hyde, K.D.; Norphanphoun, C.; Abreu, V.P.; Bazzicalupo, A.; Thilini Chethana, K.W.; Clericuzio, M.; Dayarathne, M.C.; Dissanayake, A.J.; Ekanayaka, A.H.; He, M.Q.; et al. Fungal diversity notes 603-708: Taxonomic and phylogenetic notes on genera and species. Fungal Divers. 2017, 87, 1-235. [CrossRef]

102. Luo, Z.L.; Yang, J.; Liu, J.K.; Su, H.Y.; Bahkali, A.H.; Hyde, K.D. Two new species of Helicascus (Morosphaeriaceae) from submerged wood in northern Thailand. Phytotaxa 2016, 270, 182-190. [CrossRef]

103. Hyde, K.D.; Hongsanan, S.; Jeewon, R.; Bhat, D.J.; McKenzie, E.H.C.; Jones, E.B.G.; Phookamsak, R.; Ariyawansa, H.A.; Boonmee, S.; Zhao, Q.; et al. Fungal diversity notes 367-490: Taxonomic and phylogenetic contributions to fungal taxa. Fungal Divers. 2016, 80, 1-270. [CrossRef]

104. Ariyawansa, H.A.; Hyde, K.D.; Jayasiri, S.C.; Buyck, B.; Chethana, K.W.T.; Dai, D.Q.; Dai, Y.C.; Daranagama, D.A.; Jayawardena, R.S.; Lücking, R.; et al. Fungal diversity notes 111-252-taxonomic and phylogenetic contributions to fungal taxa. Fungal Divers. 2015, 75, 27-274. [CrossRef] 
105. Rajashekhar, M.; Kaveriappa, K.M. Studies on the aquatic hyphomycetes of a sulfur spring in the Western Ghats, India. Microb. Ecol. 1996, 32, 73-80. [CrossRef] [PubMed]

106. Tsui, C.K.M.; Hyde, K.D.; Hodgkiss, I.J. Effects of glyphosate on lignicolous freshwater fungi of Hong Kong. Sydowia 2001, $53,167-174$.

107. Smits, G.; Fernández, R.; Cressa, C. Preliminary study of aquatic hyphomycetes from Venezuelan streams. Acta Botánica Venezuelica 2007, 30, 345-355.

108. Gonczol, J.; Revay, A. Fungal spores in rainwater: Stemflow, throughfall and gutter conidial assemblages. Fungal Divers. 2004, $16,67-86$.

109. Kurniawati, E.; Zhang, H.; Chukeatirote, E.; Sulistyowati, L.; Moslem, M.A.; Hyde, K.D. Diversity of freshwater ascomycetes in freshwater bodies at Amphoe Mae Chan, Chiang Rai. Cryptogam. Mycol. 2010, 31, 323-331.

110. Gonczol, J.; Revay, A. Aquatic hyphomycetes and other water-borne fungi in Hungary. Czech Mycol. 2011, 63, 133-151. [CrossRef]

111. Cai, L.; Zhang, K.; McKenzie, E.H.C.; Hyde, K.D. Freshwater fungi from bamboo and wood submerged in the Liput River in the Philippines. Fungal Divers. 2003, 13, 1-12.

112. Abdullah, S.K. Two hyphomycetes on litter in stagnant water from Britain. Trans. Br. Mycol. Soc. 1980, 75, 514-517. [CrossRef]

113. Shearer, C.A. Fungi of the Chesapeake Bay and its tributaries IV. Three new species from the Patuxent River. Mycologia 1974, 66, 16-24. [CrossRef]

114. Ingold, C.T. Camposporium marylandicum shearer from Britain. Trans. Br. Mycol. Soc. 1976, 67, 532-533. [CrossRef]

115. Gonczol, J.; Revay, A. Aquatic hyphomycetes in a tributary of the Morgo stream, Borzsony Mts, NE Hungary. Stud. Bot. Hung. 1998, 29, 5-16.

116. Czeczuga, B.; Mazalska, B.; Godlewska, A.; Muszyńska, E. Aquatic fungi growing on dead fragments of submerged plants. Limnologica 2005, 35, 283-297. [CrossRef]

117. Yang, J.; Liu, J.K.J.; Hyde, K.D.; Gareth Jones, E.B.; Luo, Z.L.; Liu, Z.Y. Aquimonospora tratensis gen. et sp. nov. (Diaporthomycetidae, Sordariomycetes), a new lineage from a freshwater habitat in Thailand. Phytotaxa 2019, 397, 146-158. [CrossRef]

118. Hyde, K.D.; Chaiwan, N.; Norphanphoun, C.; Boonmee, S.; Camporesi, E.; Chethana, K.W.T.; Dayarathne, M.C.; de Silva, N.I.; Dissanayake, A.J.; Ekanayaka, A.H.; et al. Mycosphere notes 169-224. Mycosphere 2018, 9, 271-430. [CrossRef]

119. Yang, J.; Liu, J.K.; Hyde, K.D.; Jones, E.B.G.; Liu, Z.Y. Two new species in Fuscosporellaceae from freshwater habitats in Thailand. Mycosphere 2017, 8, 1893-1903. [CrossRef]

120. Yang, H.; Dong, W.; Yu, X.D.; Bhat, D.J.; Boonmee, S.; Zhang, H. Four freshwater dematiaceous hyphomycetes in Sordariomycetes with two new species of Parafuscosporella. Phytotaxa 2020, 441, 19-34. [CrossRef]

121. Li, G.J.; Hyde, K.D.; Zhao, R.L.; Hongsanan, S.; Abdel-Aziz, F.A.; Abdel-Wahab, M.A.; Alvarado, P.; Alves-Silva, G.; Ammirati, J.F.; Ariyawansa, H.A.; et al. Fungal diversity notes 253-366: Taxonomic and phylogenetic contributions to fungal taxa. Fungal Divers. 2016, 78, 1-237. [CrossRef]

122. Palavutitotai, N.; Chongtrakool, P.; Ngamskulrungroj, P.; Chayakulkeeree, M. Nocardia beijingensis psoas abscess and subcutaneous phaeohyphomycosis caused by Phaeoacremonium parasiticum in a renal transplant recipient: The first case report in Thailand. Southeast Asian J. Trop. Med. Public Health 2015, 46, 1049-1054. [PubMed] 